\title{
Hanford Groundwater Scenario Studies
}

R. C. Arnett

R. E. Gephart

R. A. Deju

C. R. Cole

S. W. Ahlstrom

\section{May 1977}

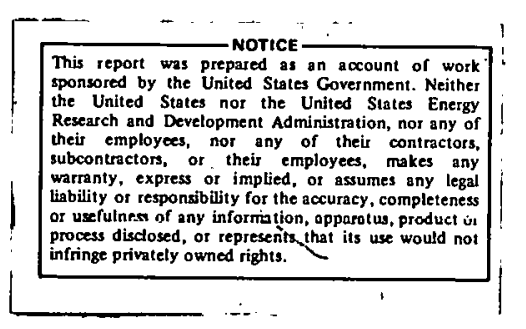

Prepared for the U.S. Energy Research and Development Administration Under Contract EY-76-C-06-2130

Atlantic Richfield Hanford Company Richland, Washington 99352

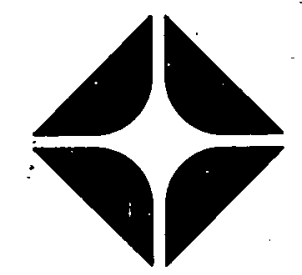




\section{DISCLAIMER}

This report was prepared as an account of work sponsored by an agency of the United States Government. Neither the United States Government nor any agency Thereof, nor any of their employees, makes any warranty, express or implied, or assumes any legal liability or responsibility for the accuracy, completeness, or usefulness of any information, apparatus, product, or process disclosed, or represents that its use would not infringe privately owned rights. Reference herein to any specific commercial product, process, or service by trade name, trademark, manufacturer, or otherwise does not necessarily constitute or imply its endorsement, recommendation, or favoring by the United States Government or any agency thereof. The views and opinions of authors expressed herein do not necessarily state or reflect those of the United States Government or any agency thereof. 


\section{DISCLAIMER}

Portions of this document may be illegible in electronic image products. Images are produced from the best available original document. 


\section{Atlantic Richfield Hanford Company \\ Richland, Washington 99352}

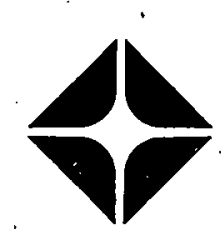

\section{NOTICE}

THIS REPORT WAS PREPARED AS AN ACCOUNT OF WORK SPONSORED BY THE UNITED STATES GOVERNMENT. NEITHER THE UNITED STATES NOR THE UNITED STATES ENERGY RESEARCH AND DEVELOPMENT ADMINISTRATION, NOR ANY OF THEIR EMPLOYEES, NOR ANY OF THEIR CONTRACTORS, SUBCONTRACTORS, OR THEIR EMPLOYEES, MAKES ANY WARRANTY, EXPRESS OR IMPLIED, OR ASSUMES ANY LEGAL LIABILITY OR RESPONSIBILITY FOR THE ACCURACY, COMPLETENESS, OR USEFULNESS OF ANY INFORMATION, APPARATUS, PRODUCT OR PROCESS DISCLOSED, OR REPRESENTS THAT. ITS: USE WOULD NOT INFRINGE PRIVATELY OWNED RIGHTS. 


\title{
HANFORD GROUNDWATER \\ SCENARIO STUDIES
}

\author{
R. C. Arnett \\ R. E. Gephart \\ R. A. Deju \\ C. R. Cole* \\ S. W. Ahistrom* \\ Research Department \\ Research and Engineering Division
}

* Water arid Land Resources Department

Battelle, Pacific Northwest Laboratories

Richland, Washington. 99352

May 1977

ATLANTIC RICHFIELD HANFORD COMPANY

RICHLAND, WASHINGTON 99352

To be presented at the

American Geophysical Union

1977 Spring Meeting

Washington, D.C.

May 30 - June 3, 1977

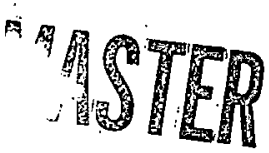


This report documents the results of two Hanford groundwater scenario studies. The first study examines the hydrologic impact of increased groundwater recharge resulting from agricultural development in the cold Creek Valley located west of the Hanford Reservation. The second study involves recovering liquid radioactive waste which has leaked into the groundwater flow system from a hypothetical buried tank containing highlevel radioactive waste. The predictive and control sapacity of the onsite Hanford modeling technology is used to evaluate both scenarios.

The results of the first study indicate that Cold Creek Valley irrigation is unlikely to cause significant changes in the water table underlying the high-ievel waste areas or in the movement of radionuclides already in the ground water. The hypothetical tank leak study showed that an active response (in this case waste recovery) can be modeled and is a possible alternative to passive monitoring of radionuclide movement in the unlikely event that high-level waste is introduced into the ground water. 


\section{TABLE OF CONTENTS}

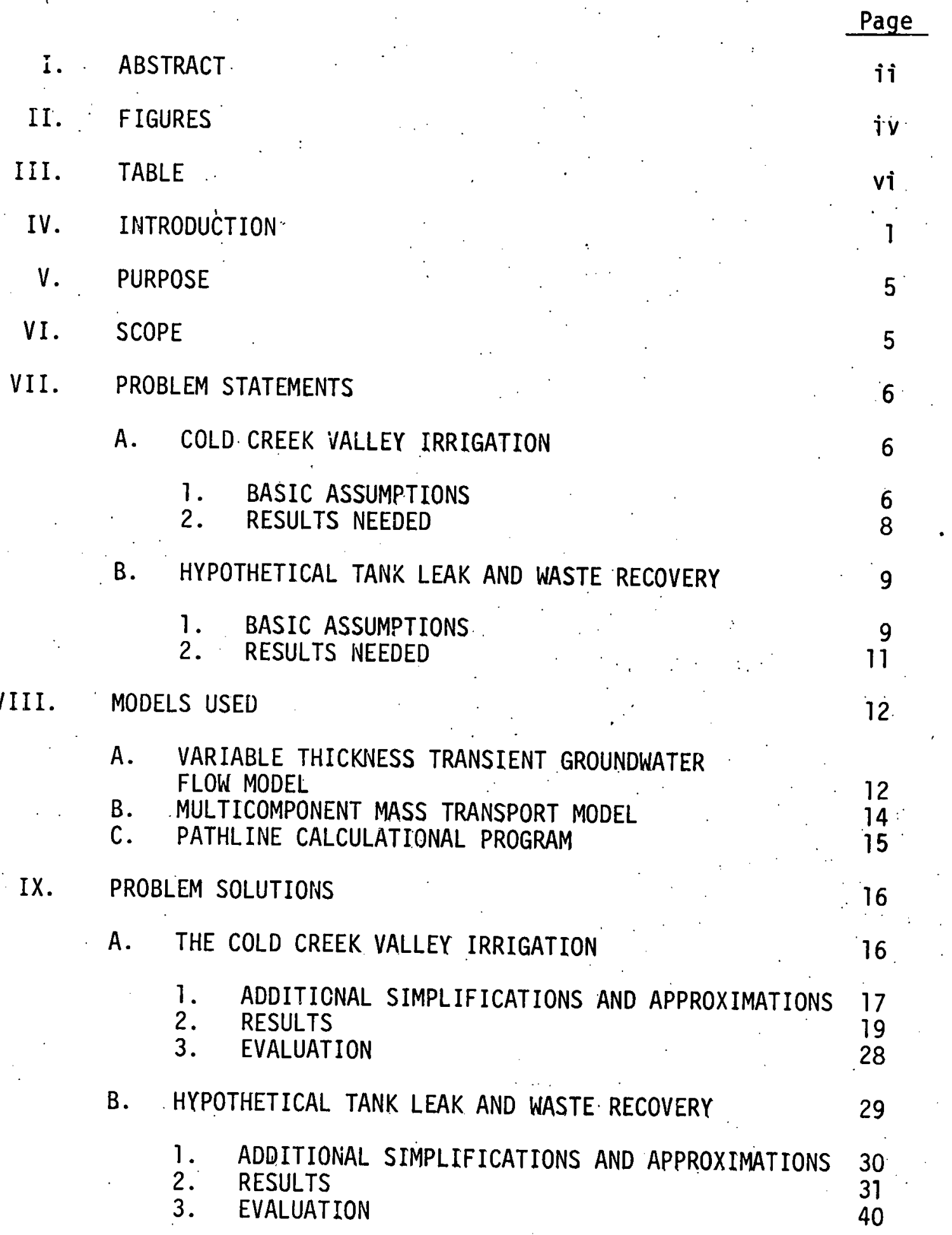

$X$ CONCLUSIONS $\quad 41$

XI. REFERENCES 42 


\section{LIST OF FIGURES}

Figure

Number

Page

1 . HANFORD AREA MAP 2

2 HANFORD GROUNDWATER SYSTEM TECHNICAL EVALUATION AND MANAGEMENT PROCEDURE

3 POSITION OF THE COLD CREEK VALLEY AREA SUBJECTED TO HYPOTHETICAL IRRIGATION

4 LOCATION OF THE HYPOTHETICAL TANK LEAK IN THE 200 EAST AREA

5 , GRID PATTERN USED IN VTT SIMULATION - 2000 FOOT GRID

6 PREDICTED STEADY STATE GROUNDWATER HEAD CONTOURS WITHOUT IRRIGATION

7 PREDICTED STEADY STATE GROUNDWATER HEAD CONTOURS WITH COLD CREEK IRRIGATION

8 ULTIMATE INCREASE IN GROUNDWATER LEVELS RESULTING FROM THE HYPOTHETICAL COLD CREEK IRRIGATION

9 COMPARISON OF PREDICTED TRITIUM CONCENTRATION PATTERNS FOR JANUARY 1981 WITH AND WITHOUT COLD CREEK IRRIGATION STEADY STATE FLOW ANALYSIS

10 COMPARISON OF PREDICTED TRITIUM CONCENTRATION PATTERNS. FOR JANUARY 1981 . WITH AND WITHOUT COLD CREEK IRRIGATION TRANSIENT FLOW ANALYSIS

11 STREAMLINES FROM 200 WEST AREA FOR THE NONIRRIGATION (BASE) CASE

12 STREAMLINES FROM THE 200 WEST AREA FOR THE CASE INVOLVING. COLD CREEK VALLEY IRRIGATION

13 PREDICTED SUBREGION POTENTIAL CONTOURS PRIOR TO ENTRY OF HYPOTHETICAL TANK LEAK WASTE INTO GROUND WATER

14 PREDICTED SUBREGION POTENTIAL CONTOURS IMMEDIATELY FOLLOWING ENTRY OF HYPOTHETICAL TANK LEAK WASTE INTO THE GROUND WATER 32 
15 PREDICTED SUBREGION POTENTIAL CONTOURS 31 DAYS AFTER WASTE ENTRY INTO GROUND WATER AND IMMEDIATELY PRIOR TO RECOVERY OPERATIONS

16 RUTHENIUM CONCENTRATION CONTOURS JUST PRIOR TO RECOVERY OPERATIONS

17 PREDICTED SUBREGION POTENTIAL CONTOURS AFTER 60 DAYS OF RECOVERY PUMPING AT $150 \mathrm{GPM}$ (50 GPM. FOR EACH OF 3 WELLS)

18 RUTHENIUM-106 CONCENTRATION CONTOURS AFTER 60 DAYS RECOVERY PUMPING AT 150 GPM (50 GPM FOR EACH OF 3 WELLS)

19 RUTHENIUM-106. CONCENTRATION CONTOURS AFTER 90 DAYS OF RECOVERY PUMPING AT $150 \mathrm{GPM}$ (50 GPM EACH FOR 3. WELLS)

20 RUTHENIUM-106 CONCENTRATION CONTOURS AFTER 240 DAYS OF RECOVERY PUMPING AT 150 GPM (50 GPM EACH FOR 3 WELLS)

21 SUBREGION POTENTIAL CONTOURS AFTER 60 DAYS OF RECOVERY PUMPING AT 325 GPM (125 GPM AT WELL A, AND $100 \mathrm{GPM} \mathrm{EACH}$ AT WELLS B AND C)

22 RUTHENIUM-106 CONCENTRATION CONTOURS AFTER 60 DAYS OF RECOVERY PUMPING AT 325 GPM (125 GPM AT WELL A AND 100 GPM EACH AT WELLS B AND C)

23 RUTHENIUM-106 CONCENTRATION CONTOURS AFTER 135 DAYS OF RECOVERY PUMPING AT 325 GPM (125 GPM AT WELL A, AND 100 GPM EACH AT WELLS B AND C)

24 STREAML INE FROM THE HYPOTHETICAL TANK LEAK LOCATION TO THE COLUMBIA RIVER (TRAVEL DISTANCE $=17.5$ MILES, TRAVEL TIME $=125$ YEARS) 


\section{TABLE}

Table

Number

$\underline{\text { Page }}$

1 COMPARISON OF TRAVEL TIMES AND TRAVEL DISTANCES

OF STEAMLINES STARTING FROM THE 200 WEST AREA. 


\section{INTRODUCTION}

Since 1.944 the Hanford Reservation, located in south-central... Washington, has been a site for radioactive waste storage, reactor development, and chemical separation facilities for the production and purification of plutonium. [1] The radioactive waste storage and chemical separation facilities are located within the high-level radioactive waște areas rabeled 200-West and 200-East on Figure. 1. The plutonium production reactors (only one is currentiy operational) are located along the Columbia River in the 100 areas. Laboratory facilities (300 Area), an important testing facility of the national breeder reactor program called the Fast Flux Test Facility (FFTF), and several commercial nuclear power reactors operated by the Wastington Public Power Supply System (WPPSS) are also located on the Reservation.

Waste management has involved the disposal of some radionuclides to surface disposal. sites with consequent contamination of some aquifers underlying the Reservation. An extensive groundwater monitoring program conducted over the years at Hanford indicates that the movement of radioactive contaminants through the groundwater flow system toward biosphere uptake points (primarily the Columbia River) is rather limited. ${ }^{[2]}$ Nevertheless, a program is being conducted to assure continued isolation of such contaminants from the biosphere both now and in the future.

At present, the Atrantic Richfield Hanford Company (ARHCO) operates the waste management activities at Hanford under contract to the U.S. Energy Research and Development Administration (ERDA). A Groundwater Management program has been instituted in support of the waste management activities to achieve the following management goals:

1) identify potential ways in which ground water can come in contact with high-level radioactive wastes;

2) assess data gathering and computer modeling requirements needed for long-tern prediction of subsurface contaminant migration from high-level radioactive waste areas into and through the groundwater flow system; 


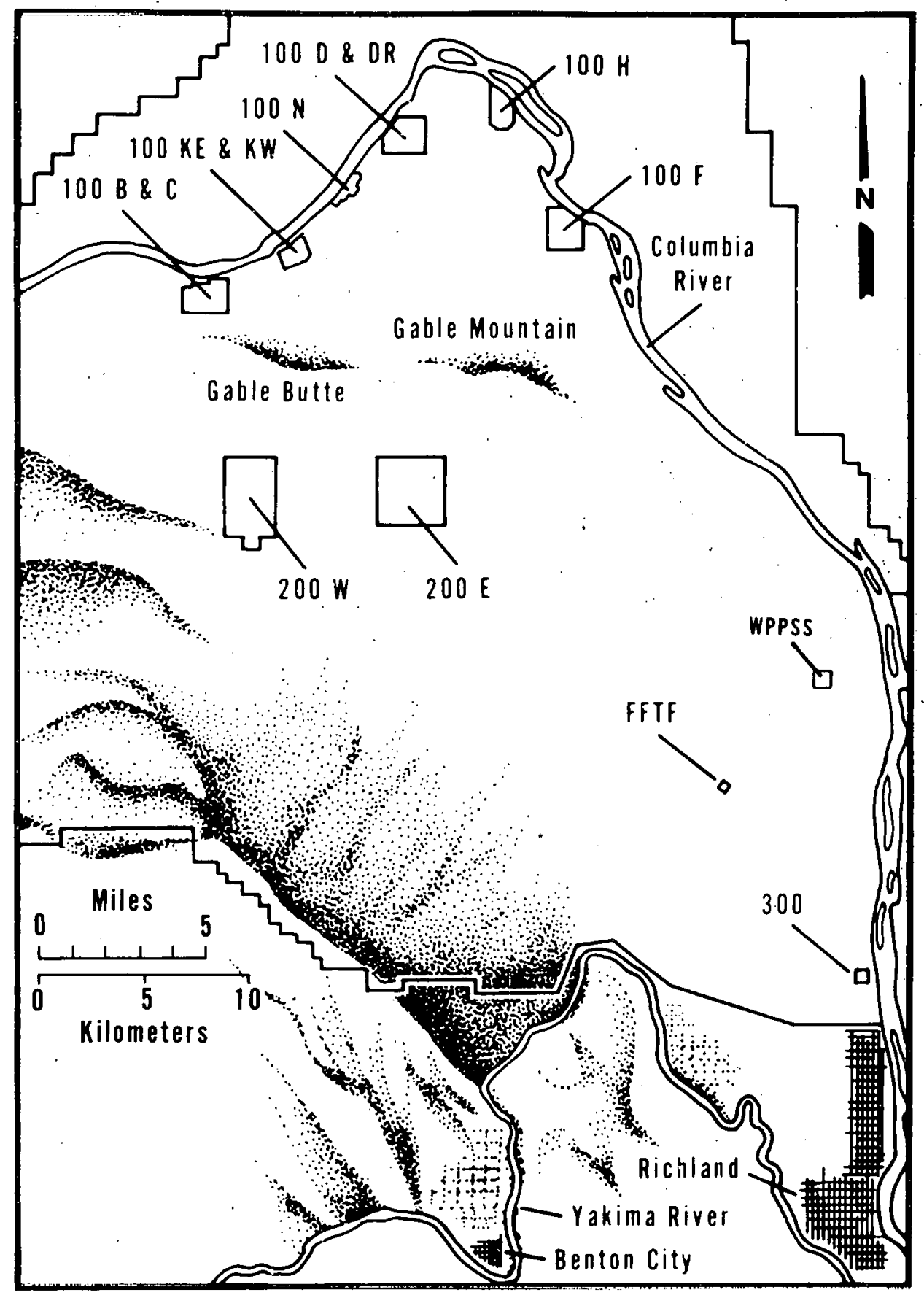

FIGURE 1

HANFORD AREA MAP 
3) examine the potential impact to the high-level radioactive waste areas resulting from past, present, and projected: activities at Hanford, potentially hazardous incidents, and: potential or existing water use activities adjacent to or within the Hanford Reservation; and

4) improve the management of the Hanford flow regime and identify methods of controiling accidental contaminant releases and preventing the contarninant from reaching the biosphere.

The steps in the technical evaluation and mariagenient of the Hanford groundwater system are depicted in Figure 2. System characterization is established through data collection and interpretation which lead to a conceptual model of the system. Such a conceptual model may be used. directly for environmental assessment and management decision purposes or it may first be translated into mathematical form amenable to analytical or computer solution.methods. Further discussion of this approach is presented elsewhere. [3]

The sophistication and detail required in the data base, conceptual model (s) and mathematical model (s) depend upon the type and precision of the results needed. An excellent method for determining whether the. desired results can be achieved is to test the technical tools with a series of problem "scenarios." In this approach, potentially important changes in activities, faciitities, or natural conditions are identified and existing data, knowledge, and methods are utiiized to predict the consequences of such changes upon the groundwater system. Likewise the existence of unverified. natural conditions within the groundwater system may be postulated and the impact of such conditions evaluated. The existence of significant interflow between different aquifers would be an example of such a possible but unverified condition. Incorrect results may arise from defects or insufficiencies in the characterization, conceptual models(s), mathematical model(s), or the associated computer codes. Under such circumstances, the problem should be idenified and corrective measures implemented in a feedback loop. 


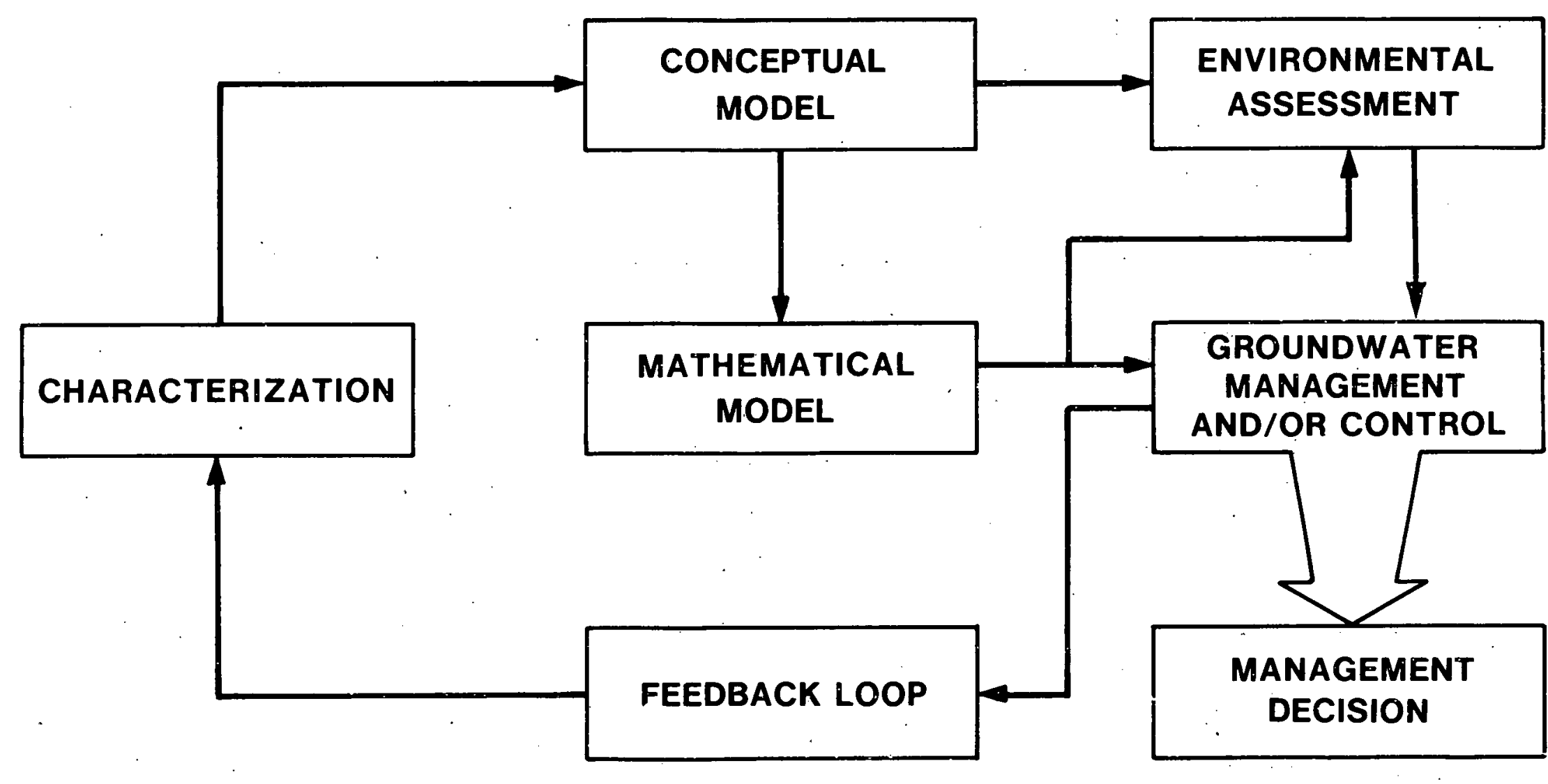

$v 7606 \cdot 23.1$

FIGURE 2

HANFORD GROUNDWATER SYSTEM

TECHNICAL EVALUATION AND

MANAGEMENT PROCEDURE 
As confidence is established in the conceptual and mathematical descriptions and tools, the relative consequences of al ternative activities or new facilities affecting the groundwater systems can be presented for evaluation. Similarly, al ternative methods of controlling or reducing adverse consequences can be stüdied.

\section{'PURPOSE}

This report documents the results of the first two of a planned series of Hanford groundwater scenario studies. The first study examines the hydrologic impact of increased groundwater recharge resulting from possible agricultural development in the Cold Creek Valley located west of the Hanford Reservation. The second study involves the recovery of liquid radioactive waste which is simulated to have leaked into the unconfined groundwater flow system from a hypothetical buried tank containing high-level radioactive waste. By evaluating these scenarios the onsite computer modeling capability is being initially evaluated for its predictive and control technology uses. This will optimize future modeling development and adaptation.

\section{SCOPE}

In the Cold Creek Valley study heavy irrigation is postulated for the area believed to be the major natural recharge zone for the Hanford unconfined aquifer. The fraction of such irrigation water reaching the ground water and supplementing natural flow is estimated and the impact of the increased groundwater flow upon the high-level radioactive waste areas is predicted. This study addresses the first, second, and third management goals described above with emphasis upon the third goal.

In the second scenario stuidy involving a hypothetical 200 East Area waste tank leak, a large fraction of the waste is postulated to reach the ground water. Methods and techniques of recovering and controliling the movement of the waste toward the biosphere uptake points are examined. This tank leak scenario study addresses all four management goals described above. 
Because of the complexity of the problems posed herein, a set of available computer models were used. The general status of the Hanford Groundwater Modeling program is documented elsewhere. [3] Since one of the primary purposes of these studies was to test the available solution capability, an effort was made to avoid biasing the problem statements towards the strengths of that same model capability. The problems were formulated primarily by ARHCO hydrologists not intimately familiar with the strengths and weaknesses of available models. They were asked to pose the problems only in terms of the value of the expected results to the Hanford Groundwater Management Program.

\section{PROBLEM STATEMENTS}

\section{COLD CREEK VALLEY IRRIGATION}

The problem examines the effect of increased agricultural irrigation in the Cold Creek Valley located just west of the Hanford Reservation. An alfalfa crop is assumed grown over a ten (10) square mile area within the valley (Figure 3). This crop has one of the greatest irrigation requirements of any crop grown in this portion of Washington. [4] The seasonal irrigation needed to assure adequate water quantities $95 \%$ of the time is 50 inches (127 centimeters) per year.

The growing season lasts seven months (April-0ctober). During this time, evapotranspiration and other losses consume 85 percent of the irrigated water. [4] The remaining $1.3 \times 10^{9}$ gallons $\left(4.9 \times 10^{9}\right.$ liters) are assumed to saturate the soil column and recharge the underlying unconfined aquifer. This infiltration averages 4220 gallons per minute (16,000 liters per minute) over the ten square miles during the sevenmonth growing season. No irrigation is required from November through March.

\section{BASIC ASSUMPTIONS}

1. Irrigated land is flat.

2. Average water depth is 150 feet (46 meters). [5] 
ARH-SA-292

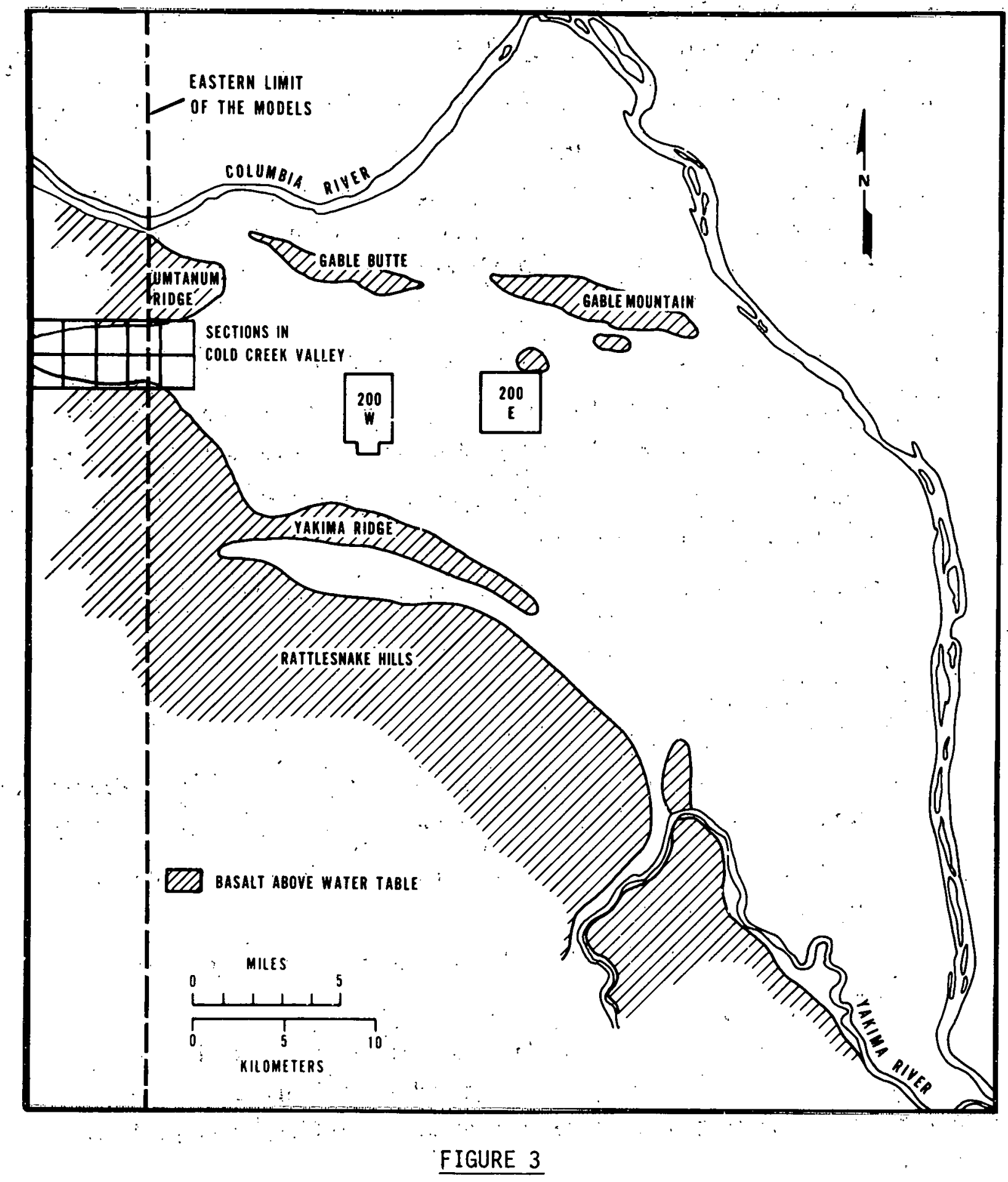

POSITION OF THE COLD CREEK VALLEY AREA SUBJECTED TO HYPOTHET ICAL IRRIGATION 
3. A.verage depth to basalt is 400 feet (122 meters). [6]

4. Average hydraulic conductivity value for saturated sediment is $300 \mathrm{feet} /$ day ( 100 meters/day). [7]

5. A total of 10 square miles ( 25.9 square kilometers) is under irrigation.

6. The unconfined aquifer underlying the irrigated area is uniformiy recharged during the growing season $1.3 \times 10^{9}$ gallons $\left(4.9 \times 10^{9}\right.$ 1 iters) or an average of 4220 gallons per minute $(16,000.1 \mathrm{pm})$ of irrigation water.

7. The irrigation rate is constant over the growing season.

8. Irrigation water is withdrawn from a source other than the unconfined aquifer such as the confined aquifers or the Columbia River.

9. Minimum distance between the irrigated land and the 200 West Area is 5 miles (eight kilometers).

10. No radioactive or other contamination is associated with the irrigation.

RESULTS NEEDED

The best currently availäble models were used to:

1. examine the five-year impact and the long-term impact (to steady-state conditions) of the proposed irrigation on the Hanford water table,

2. examine the effect of the irrigation upon radionuclide transport from the 200 Areas, and

3. determine the influence of irrigation on existing contaminant plumies.

A brief evaluation of the models' ability to successfully handle this type of problem is given along with additional approximations other than those in published reports needed to refine or simplify the problem. 
HYPOTHETICAL TANK LEAK AND WASTE RECOVERY

This problem considers a scenario involving the total failure of a hypothetical radioactive waste storage tank located in the 200-East Area wherein 250,000 gallons are assumed to reach the water table. The contaminant is assumed to be ruthenium-106 at a concentration of 190,000 microcuries/gallon (50,000 microcuries/liter) upon reaching the water table. Analysis and actual field measurements of accidental high-level radioactive waste discharges to the Hanford subsurface have shown limited radionuclide movement toward the water table. The introduction of 250,000 gallons of such waste into the ground water even from a total waste tank failure is unlikely. The intent of this scenario is to analyze a method of actively responding to such an event should it occur and preventing an adverse environmental impact. The location of the hypothetical tank is shown in Figure. 4 ..

Within 30: days of the waste material reaching the water table, groundwater wells are drilled at the leak site: One or more waste recovery wells are centrally drilled over the groundwater mound formed by the leak. These discharge wells will be used to withdraw the contaminated water. Four or more injection wells may be drilled along the mounds' outer perimeter. These wells are used to contain and retard the movement of the waste solution while the discharge well removes it. Either air or water may be injected into the groundwater system through the injection wells. The minimal number of wells should be drilled to contain the leak and withdraw the contamination.

BASIC ASSUMPTIONS

1. The tank leak was placed in a 200-East Area location shown in Figure 4.

2. A total of 250,000 gallons $(950,000$ liters $)$ of waste solution is assumed to reach the water table. 


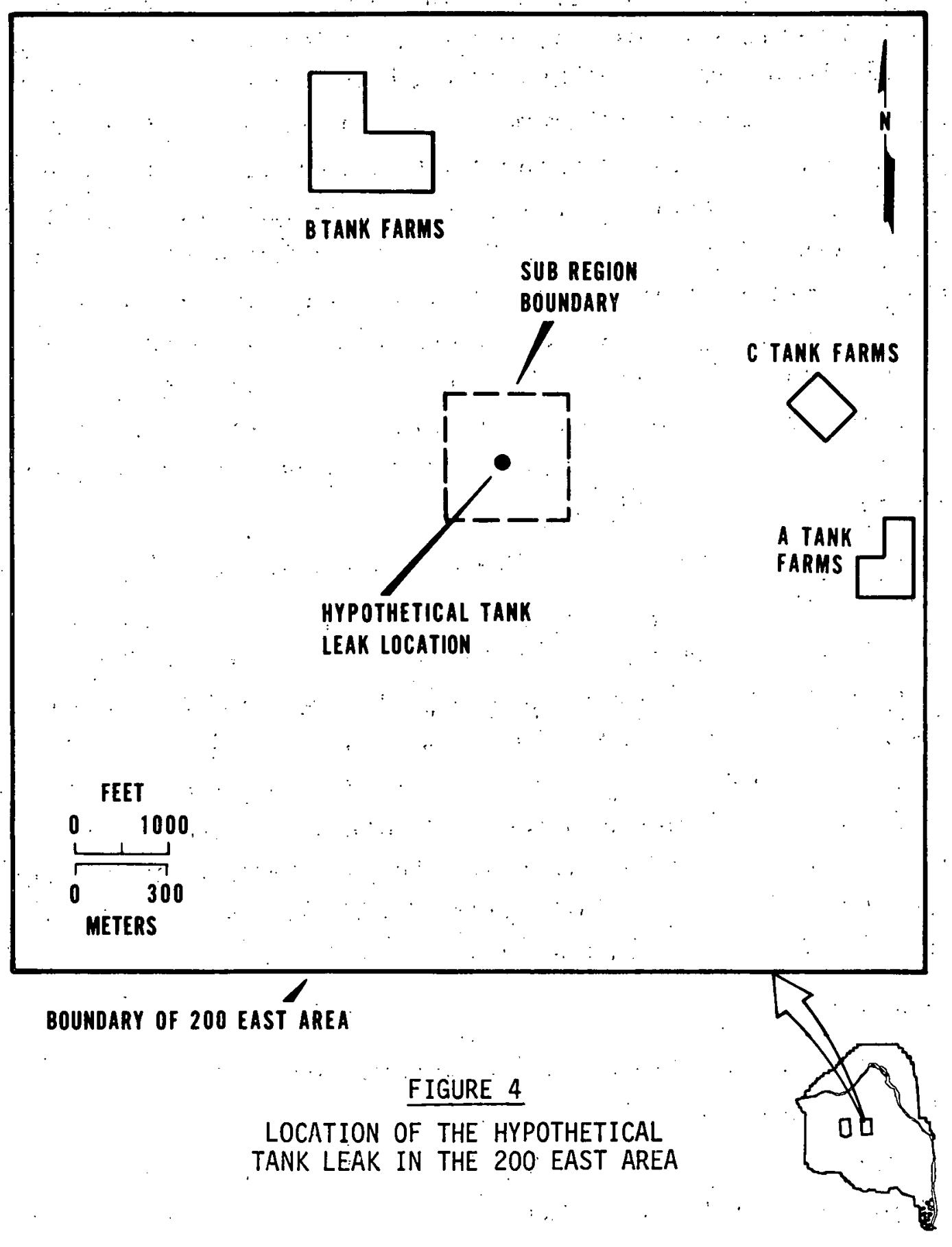


3. Concentration of waste solution upon reaching water table is 190,000 microcuries/gallon (50,000 microcuries/1iter) calculated as ruthenium-i06.

4. Average depth to water is 290 feet ( 88 meters). [5]

5. Average depth to basalt is 350 feet (107 meters). [8]

6. Average porosity is 25 percent.

7. Average hydraulic conductivity $(K)$ is 1000 feet/day ( 300 meters/day). [7]

8. Injection and discharge wells drilled within 30 days of the leak will be used to contain and remove contamination.

9. Injected fiuid is either air or water.

RESULTS NEEDED

The best currently available models were used to:

1. provide best location and design of injection and discharge wells relative to the tank leak,

2. Show the contaminant concentration versus time from the moment the waste enters the grouridwater until pumping is complete, and

3. evaluate the optimum discharge rate to remove the contamination.

A brief evaluation of the models' ability to successfully handle this type of problem is given along with additional approximations other than those in published reports needed for problem refining or simplification. 
MODELS USED

A flow and two contaminant transport models were used for the two scenario studies addressed in this report. The flow model is termed the Variable Thickness Transient (VTT) Model and serves as input to the two transport models. These are the Multicomponent Mass Transport Discrete Parcel Random Walk Model (MMT-DPRW) and the Hanford Pathline Calculational Program (HPCP).

VARIABLE THICKNESS TRANSIENT GROUNDWATER FLOW MODEL MATHEMATICAL FORMULATION

The Variable Thickness Transient (VTT) ${ }^{[9]}$ Model was used to study changes in the water table by simulating the flow of an incompressible fluid that saturates a rigid, porous soil matrix. In this model the hydraulic conductivity $(K)$ is assumed to be isotropic but heterogeneous and Darcy's law is presumed to govern the flow: The basic equation upon which the model is constructed is known as the Boussinesq equation of unsteady flow. This formulation assumes that a two-dimensional (areal) formulation is adequate and consequentially all of the aquifer properties are represented by their average over the saturated thickness of the aquifer. The variations of the aquifer thickness with space are considered, however, and the free-surface boundary condition with accretion is incorporated into: the differential equation. Seepage surfaces are neglected in this model in order to carry out the averaging in the vertical direction.

The basic computer model based on the above assumptions and equation is described in detail by Kipp, et al., [9] with the exception of some recent improvements. The model provides a means of applying a specific set of boundary conditions to the above equations in order to produce a transient simulation.

The VTT model uses data on a square grid pattern, each square being 2000 feet ( 610 meters) on a side (Figure 5). The Columbia River bounds the region on the north and east. The western and southern sides are 
13

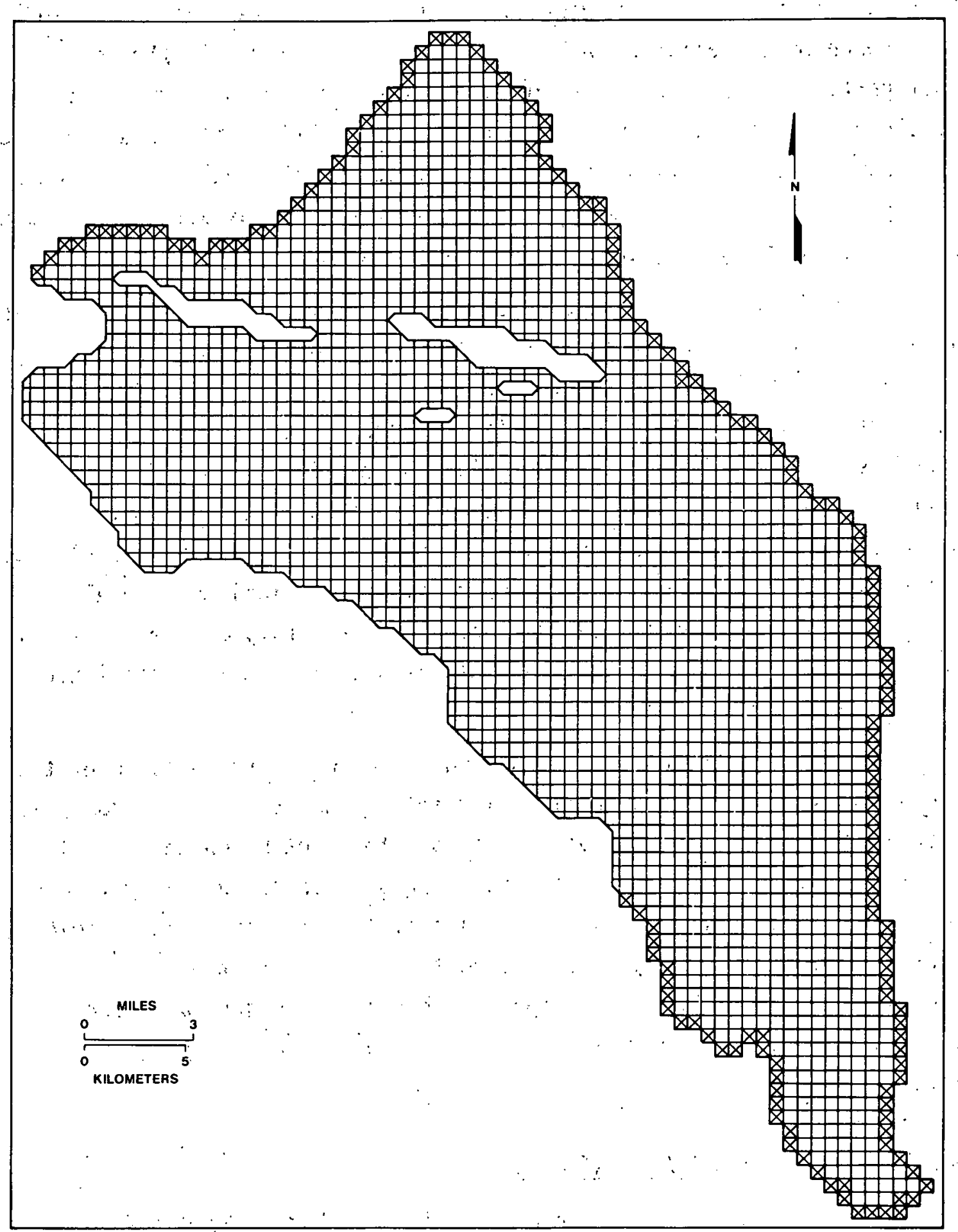

FIGURE. 5 .

GRID, PATTERN USED, IN VTT SIMULATION - 2000 FOOT GRID 
bounded irregularly by the Umtanum, Yakima, and Rattlesnake ridges and are broken by two alluvial valleys and the Yakima River in the southernmost part. The east-west trending void areas in the northern portion of the Reservation as shown in Figure 5 are basaltic outcrops and as such are assumed to be no-flow areas. Water entering the region from the valley alluvium is accounted for in the model as a flux across the boundary such that the proper water tabie elevation is maintained.

The VTT Model can operate in a regional (far-field mode) as well as a subregional (near-field mode). Data utilized in the model have been developed over an extensive period of time as part of the Hanford Waste Management Program. Modeling consists of one or more computer runs for each case examined. A regional simulation over the area in Figure 5 reflects the effective aquifer stresses and yields a potentiometric surface from which boundaries may be interpolated for a subregional model. The subregional model may be used to resolve the detail of a local area such as that immediately surrounding the vicinity of the hypothetical tank leak. The model can then be used to simulate localized. water injection and recovery.

The hydraulic conductivity is assumed to be heterogeneous over the Hanford Reservation. Its spatial distribution was determined from pump test data." These data were used in a computer routine which makes it possible to estimate the distribution of hydraulic conductivity throughout large areas of the Hanford Reservation. [10] Due to limited field data the storage coeficient is assumed to be constant at $0.1^{[10]}$ The aquifer bottom, necessary input to the model, is generally considered to be the top of the basalt or the top of an overlying clay unit.

\section{MULTICOMPONENT MASS TRANSPORT MODEL}

The Multicomponent Mass Transport Discrete-Parcel-Random-Walk (MMT-DPRW) Model was used to predict possible changes resulting from the postulated irrigation activities in the direction of movement and concentration of one radioactive waste species that currently exists in the unconfined aquifer beneath the Hanford Reservation. It was also 
used to predict the movement and concentration of radionuclides within the ground water resulting from the hypothetical leak and subsequent recovery operation. The version of the model used to solve the problem of interest is based on a two-dimensional, vertically averaged formulation of the transport equation and is designed to work in conjunction with the VTT Flow Model described earlier. The results of the VTT simulation were used to calculate the groundwater flow field which is one of the required inputs for an MMT-DPRW model simulation.

The MMT-DPRW code considers each of the primary transport mechanisms: advection, dispersion, and source sink terms such as radioactive decay and chemical reaction. The details of the mathematical basis of the MMT-DPRW Model are documented elsewhere. [11]

The primary information required by the MMT-DPRW Model to successfully compute a transport simulation includes a flow field (as mentioned previously) which may be variant in space and time, an initial concentration distribution map for each constituent, and a time history or projected discharge rate and location for each constituent species over the time frame to be simulated. Other required information includes a description of boundary conditions and any reactive or other nonconservative mechanisms that may be important.

\section{PATHLINE CALCULATIONAL PROGRAM}

The Hanford Pathline Calculational Program (HPCP) can be considered a simple transport model wherein only advective changes are considered. [3] Rather than predict the movement of the entire contaminant plume as does the MMT-DPRW model, the HPCP model predicts the paths (ignoring dispersion) and travel times (ignoring sorption, chemical reaction, and radioactive decay) from a contaminant source to the groundwater discharge area, usually the Columbia River. It is used as a rapid, economical, and convenient means of obtaining a basic comparison of the contaminant travel direction, travel distance, and travel times under different water table (or potential) conditions. If steady state conditions 
(static water table or potential field) are assumed, a particle released at a given source point will. always arrive at the same discharge point and the travel time from source to discharge will be constant. Such " constant pathlines are usually referred to à "streamlines".

The contaminant travel time from source to discharge predicted by the HPCP model is conservative in the sense that lateral dispersion, chemical reaction, and decay are ignored. A large longitudinal dispersion will yield nonconservative results in that it would tend to cause the contaminant to move faster than predicted by the HPCP model However, large longitudinal dispersivities will also tend to reduce the concentration of the contaminant at discharge.

The HPCP model can operate in two modes: a) calculation of accumulated time along a pathline with a constant step size or b) calculation of accumulated distance along a pathline with a constant time increment. Both modes may be operated so that pathlines travel either down or up gradient.

The transient version of the VTT flow model typically produces a prediction of the water table position or potential field at monthly intervals. The HPCP model allows the user to interpolate between time planes but it is usually not necessary to obtain time steps shorter than one month. For the steady or "streamline" version of the HPCP model, only one water table position is used.

\section{PROBLEM SOLUTIONS}

\section{THE COLD CREEK VALLEY IRRIGATION}

In order to illustrate the effect of the proposed Cold Creek irrigation described earlier, the VTT; MMT-DPRW, and HPCP models were run with and without the proposed irrigation and comparisons were made between the two sets of predicted water table levels, contaminant plumes, and streami ines: 
The existing tritium contamination plume was used as as bas for determining the impact of the irrigation upon Hanford groundwater contaminant movement.

\section{ADDITIONAL SIMPLIFICATIONS AND APPROXIMATIONS}

Apart from the basic assumptions given in the problem statement or in published reports, the following additional model simplifications were used in preparing the simulations:

1. the hypothetical irrigation recharge within the existing model boundary was distributed over corresponding model. nodes whereas irrigation in the coid Creek valley area outside model boundaries was lumped together and input into the model as an addition to boundary flow,

2. the longitudinal and lateral dispersivities used in the con-. taminant transport were 100 feet (30.5 meters) and 60 feet (18.3 meters) . respectively, and.

3: any rise in the unconfined aquifer water table will not significantly alter the vertically averaged hydraulic conductivity distribution.

The present western -limit of the VTT model (Figure 3) system includes only about $30 \%$ of the specified irrigation area within Cold Creek Valley. Extending the model boundaries would have required the addition of 9 node columns to the matrix. This would increase the equation solution calculations significantly. Assuming a potential gradient of approximately 0.003 feet/foot (the steady state groundwater level. gradient near the. Cold (reek Boundary) and a hydraulic conductivity of 300 feet per day ( 100 meters day) as specified in the problem statement, the average, groundwater travel time from the irrigated area outside the boundaries to the western model boundary would be about 40 years. The average delay of 40 years is significant in determining the transient response of the unconfined aquifer but does 
not affect the ultimate or steady state conditions. Also the actual potential gradient, hydraulic conductivity, and aquifer bottom distributions within the entire Cold Creek Valley are unknown. Extending the model to include the Cold Creek Valley would require the use of very approximate estimates of these parameters as a function of space. . In any case the VVT flow model does not consider the delay in water movement likely amounting to several years which would occur in the unsaturated zone between the land surface and the water table. For the above reasons irrigation recharge of the portions of the unconfined aquifer lying outside the model boundaries was lumped at the model boundary.

The values for the dispersivities are approximate estimates of the average values required to give a preliminary match of historical tritium movement in the Hanford unconfined aquifer system. [11] Determination of an accurate distribution of dispersivities as a function of space apears to be one of the important data needs for Hanford groundwater contaminant movement predictions. $[3,11]$ Work is planned in this area. Application of the MMT-DPRW transport model even with the approximate average dispersivity values is useful in this study as the purpose is to compare the result of the irrigation and nonirrigation scenarios.

The expected rise in the water table in the western portions of the Hanford Reservation resulting from the irrigation is less than ten percent of the total unconfined aquifer thickness. Such a rise is not expected to change the region's vertical average hydraulic conductivity values.

In planning future activities such as possible extensive irrigation within the Cold.Creek Valley, it is desirable to know if these activities would have significant adverse "effect on the rate and direction of movement of the existing subsurface contaminants." Tritium was chosen for the transport model (MMT-DPRW) studies as the representative water coincident contaminant for' severàl reasons. 
- Many tritium concentration measurements have been made throughout the Hanford unconfined aquifer. These data are the most complete. data set now available to provide initial conditions and also to check the model results.

- The current extent of measurable tritium levels defines a plume that lies beneath a substantial portion of the Hanford Reservation.

- It can be assumed that tritium will not chemically interact with the porous medium or with other dissolved species. Consequently, except for dispersion phenomena and radioactive decay, tritium can be considered water coincident. This property avoids introducing the additional uncertainties associated with sorption and other chemical reactions during this preliminary application.

The initial condition of the tritium plume was established using 1976 well data. ${ }^{[11]}$ A total of four transport simulations were computed. The movement of the plume originating in the 200 Areas was predicted from January 1976 throügh December 1980 using a steady state approach without irrigation, steady state with irrigation, transient without irrigation, and transient with irrigation flow fields. The tritium discharges in the 100 areas were not considered but all other discharge streams were held at the 1976 levels.

RESULTS

Modeling the Cold 'Creek Irrigation scenario consisted of two computer runs of the VTT flow model; one five-year transient run, and one steady state run. The MMT-DPRW model was used to simulate the five-year tritium movement using the transient flow field and the steady state flow field. The HPCP. model was used to compare: the basic streamline and travel times of water moving from the 200 West Area to the Columbia River.

The steady state flow model allows investigation of the ultimate changes in potential that might occur given a constant set of boundary conditions. The transient model can address how long it will take to reach this steady-state condition as well as the dynamic behavior resulting from time varying boundary conditions. Figures 6 through 8 indicate 
the steady state effect on potentials (or groundwater level for an unconfined aquifer) resulting from this irrigation in two different forms. Figure 6 shows the model predicted groundwater level without irrigation. Figure 7 shows the predicted groundwater level with the Cold Creek Irrigation. Figure 8 illustrates a plot of equal difference lines between the two predicted groundwater level surfaces of Figures 6 and 7. The results of the Cold Creek Irrigation Study show that at the model boundary within the Cold Creek Valley the water table would increase about 30 feet ( 9 meters) and range down to 1 foot ( 0.3 meters) or less on a north-south line passing through the east end of Gable Butte and on an east-west line passing through the west end of Gable Butte. The maximum predicted rise in the water table beneath the 200 West Area was between 6 feet (1:8 meters) and 11 feet ( 3.4 meters). The rise in water. table beneath 200 East Area was less than 1 foot (0.3 meter).

The transient simulations were computed for the period of January 1976 through December 1980. The results of this transient run indicated that the difference in groundwater level (or head) caused by the irrigation in the transient simulation are steadily becoming like the differences for the steady state simulation as shown in Figure 8 .

A comparison of the predicted January 1981 irrigation versus nonirrigation tritium distributions for the steady state and transient simulations are given in Figures 9 and 10, respectively.

The starting locations of 12 streamlines were positioned around a circle centered about the principal groundwater mound within the 200 West Area. The diameter of the circle was placed at 6,500 feet to include the principal waste sources. The streamlines: for the nonirrigation and irrigation may be compared by examining. Figures 11 and 12 respectively. 
ARH-SA-292

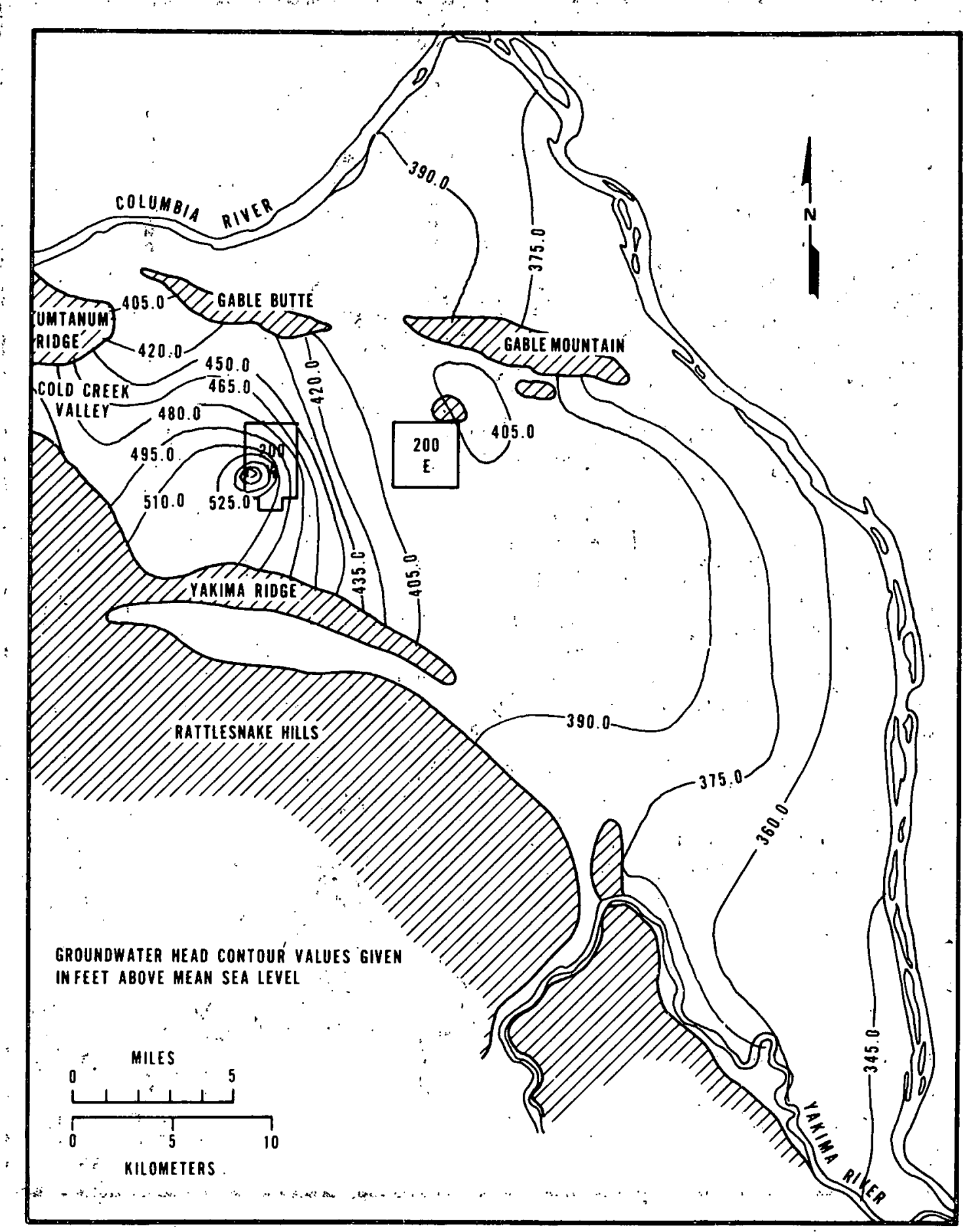

FIGÜRE 6

PREDICTED STEADY STATE GROUNDWATER HEAD CONTOURS WITHOUT IRRIGATION 


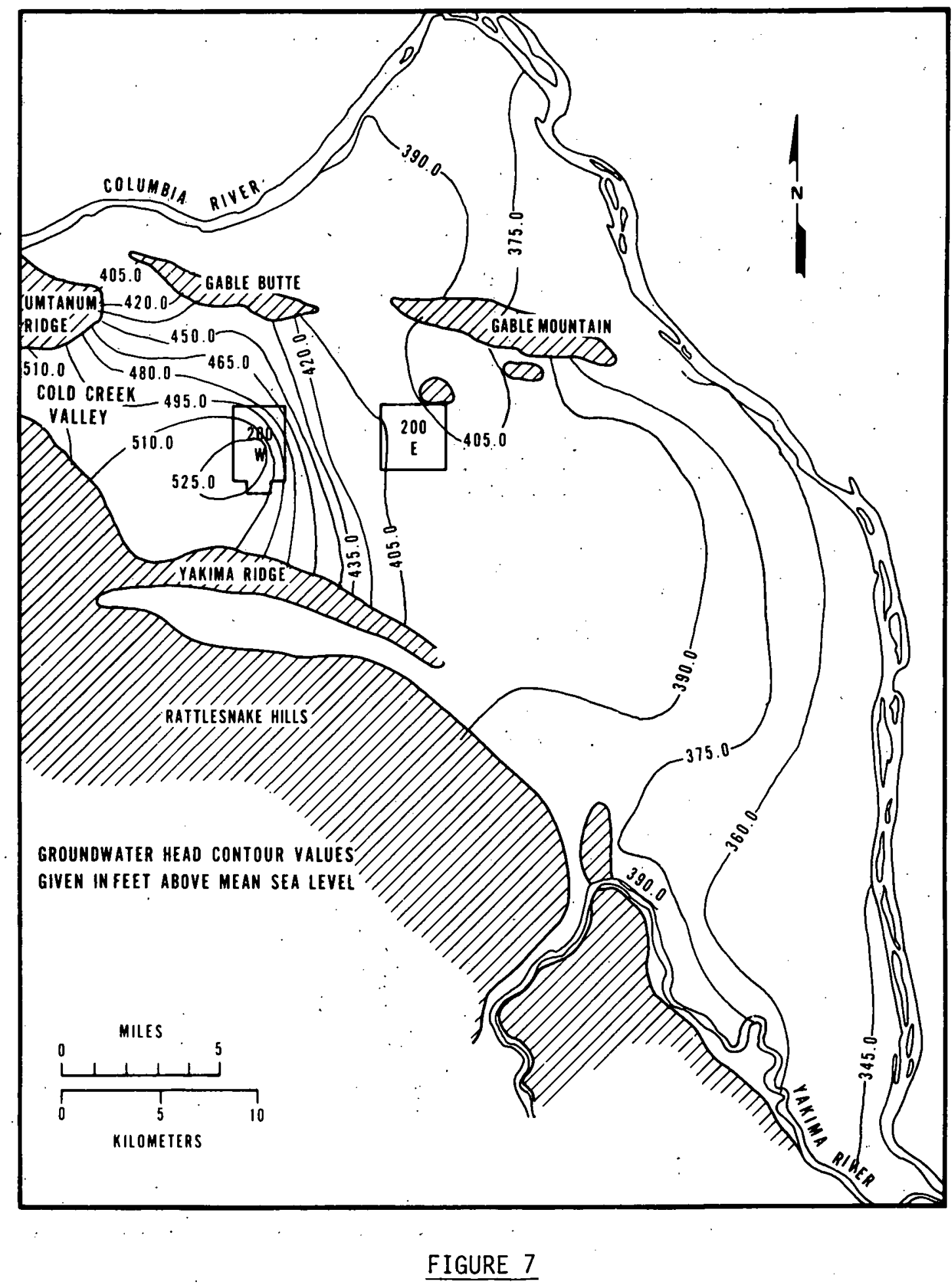

PREDICTED STEADY STATE GROUNDWATER HEAD CONTOURS WITH COLD CREEK IRRIGATION 


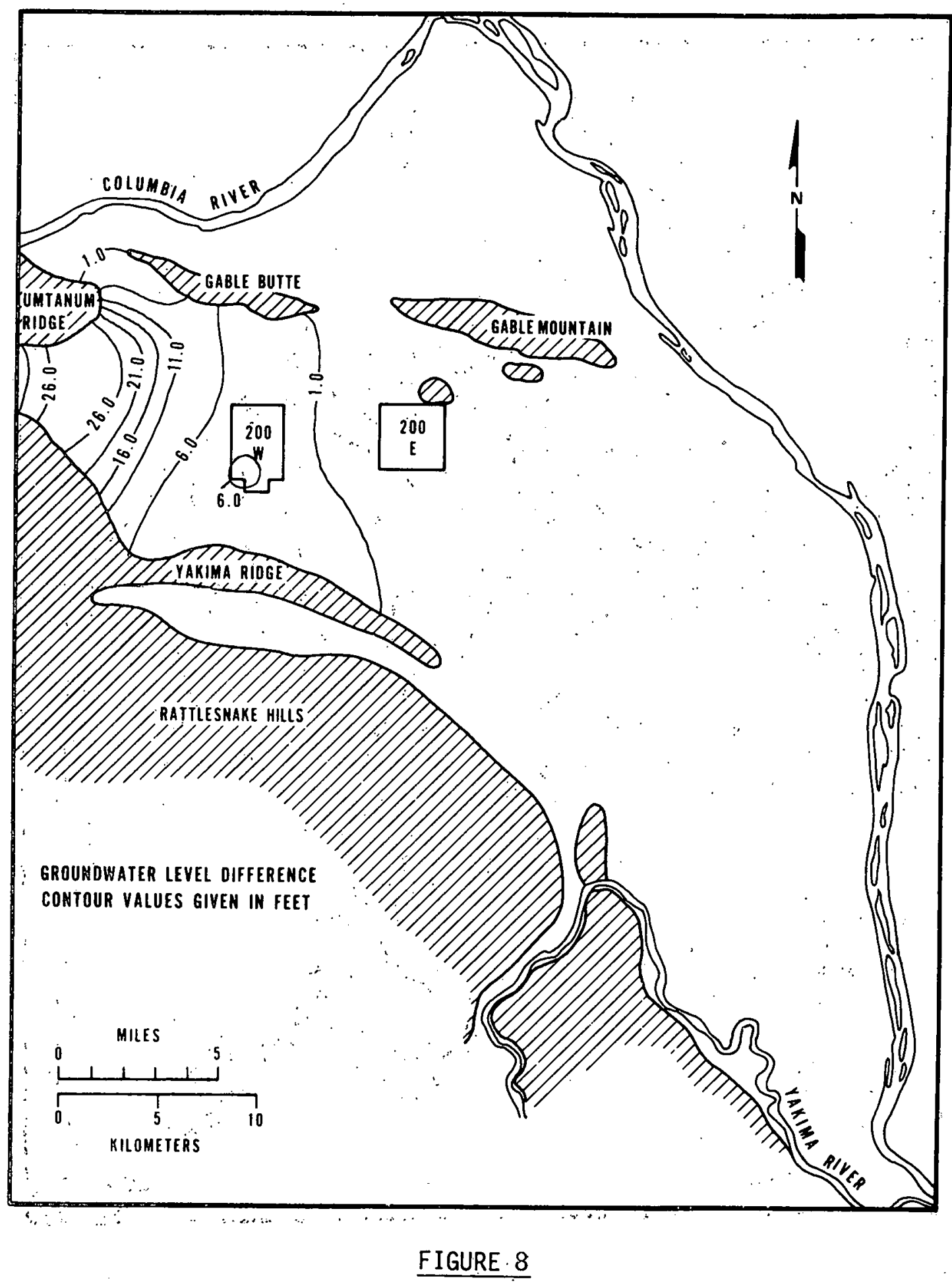

ULTIMATE INCREASE IN GROUNDWATER LEVELS RESULTING FROM THE HYPOTHETICAL COLD CREEK IRRIGATION 
ARH-SA-292



FIGURE 9

COMPARISON OF PREDICTED TRITIUM CONCENTRATION

PATTERNS FOR JANUARY 1981 WITH AND WITHOUT

COLD CREEK IRRIGATION - STEADY STATE

FLOW ANALYSIS 


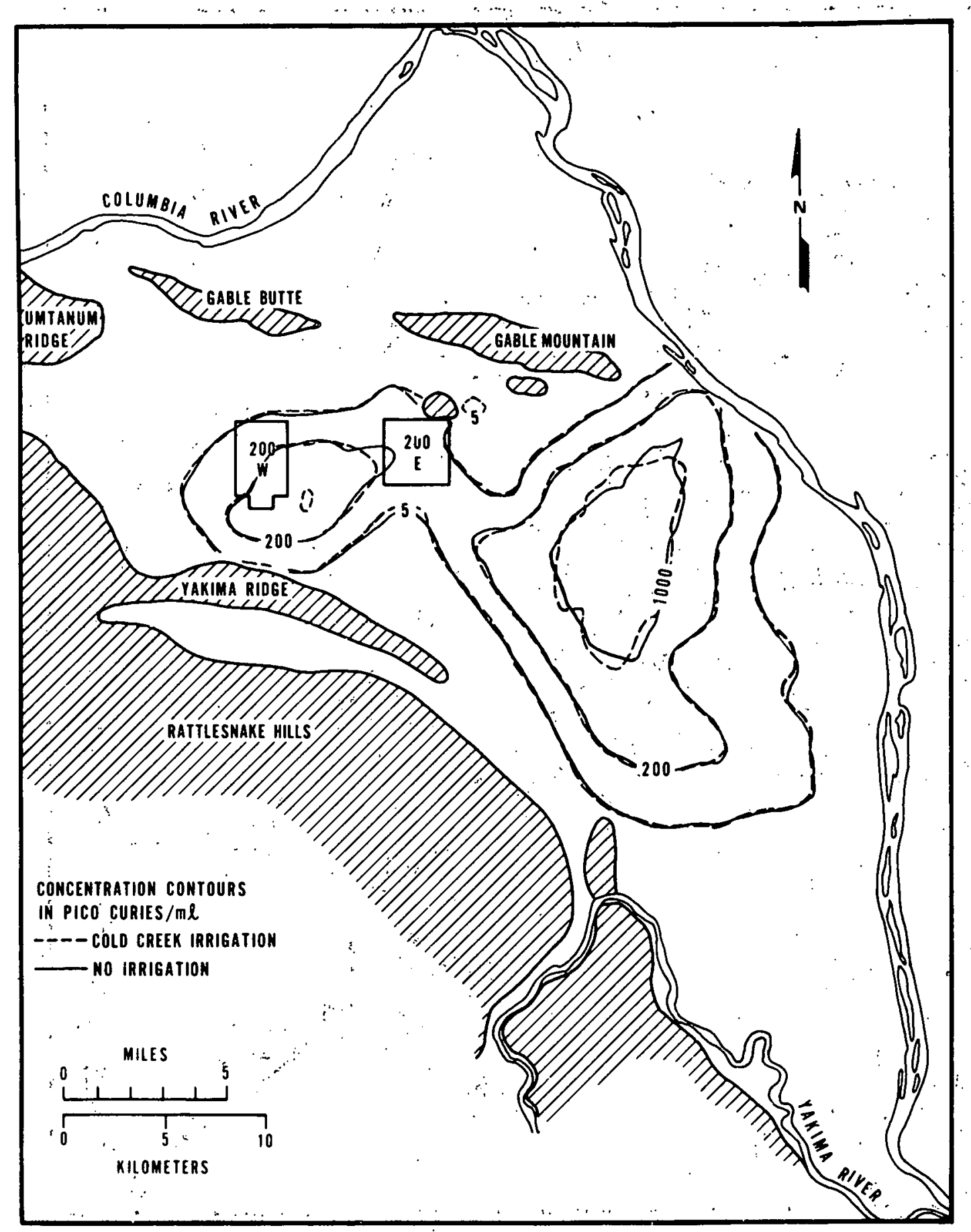

FIGURE 10

COMPARISON OF PREDICTED TRITIUM CONCENTRATION

PATTERNS FOR JANUARY 1981 WITH AND WITHOUT

COLD CREEK IRRIGATION - TRANSIENT FLOW ANALYSIS 


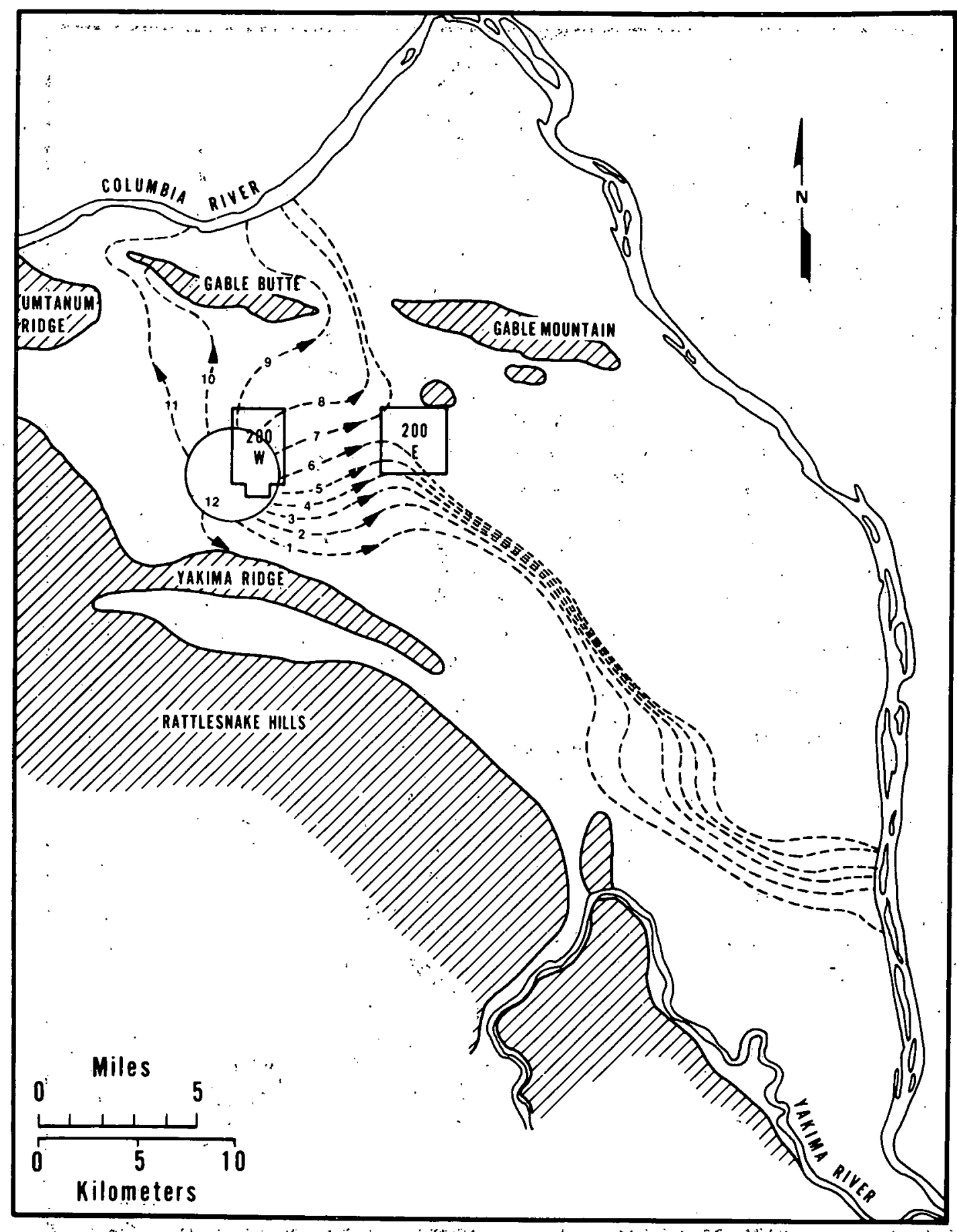

FIGURE 11

STREAMLINES FROM THE 200 WEST

AREA FOR THE NONIRRIGATION (BASE) CASE 


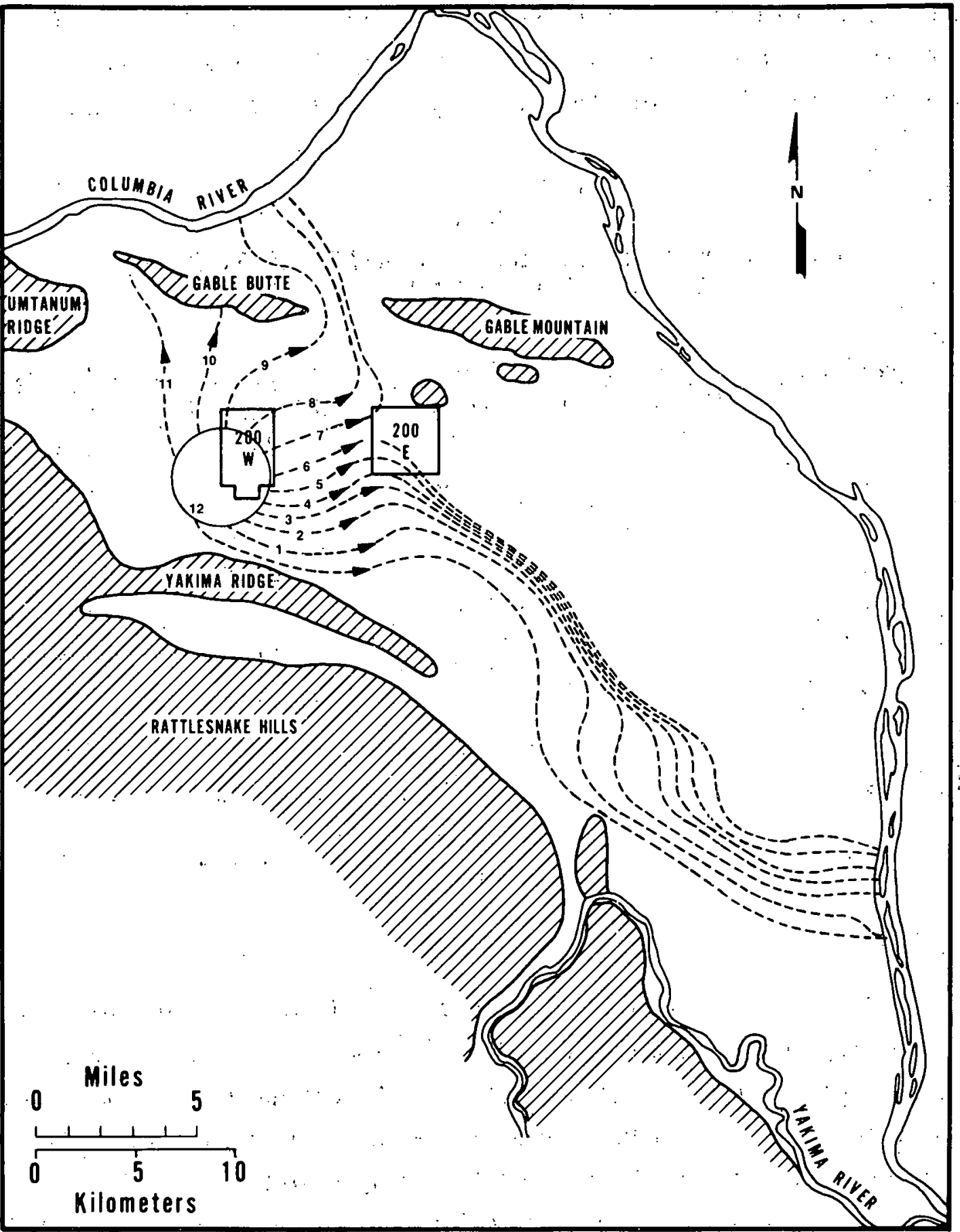

FIGURE 12

STREAMLINES FROM THE 200 WEST AREA FOR THE CASE INVOLVING COLD CREEK VALLEY IRRIGATION 
The travel times and distances for both cases are presented in Table 1. Since the termination points of streamlines 10,11 , and 12 are different in the irrigation and nonirrigation cases only the travel times and travel distances for streamlines 1-9 are presented for comparison.

\section{TABLE 1}

COMPARISON OF TRAVEL TIMES AND TRAVEL DISTANCES OF STREAMLINES STARTING FROM THE 200 WEST AREA

\begin{tabular}{|c|c|c|c|c|}
\hline Streamline & \multicolumn{2}{|c|}{ Travel Time (Years) } & \multicolumn{2}{|c|}{ Travel Distance (Miles) } \\
\hline & Nonirrigated & Irrigated & Nonirrigated & Irrigated \\
\hline 1 & 130 & 122 & 23.5 & 23.6 \\
\hline 2 & 81 & 79 & 22.4 & 22.3 \\
\hline 3 & 71 & 70 & 21.6 & 27.6 \\
\hline 4 & 69 & 70 & 21.5 & 21.4 \\
\hline 5 & 83 & 89 & 21.5 & 21.4 \\
\hline 6 & 121 & 136 & 21.5 & 21.4 \\
\hline 7 & 43 & 41 & 9.8 & 9.8 \\
\hline 8 & 63 & 59 & 9.1 & 9.2 \\
\hline 9 & 108 & 109 & 8.2 & 8.5 \\
\hline $\begin{array}{l}\text { Average of } \\
\text { treaml ines } 1-9\end{array}$ & 85 & 86 & $17.7 \div$ & 17.7 \\
\hline
\end{tabular}

\section{EVALUATION}

A brief evaluation of Figures $9,10,11$, and 12 and Table I indicates that the proposed irrigation in Cold Creek area would only have a minimal effect on the migration of contaminants in the ground water from the 200 Areas to the Columbia River. There also appeared to be little difference in this case between the plume predicted using a steady state flow assumption as opposed to a fully transient. flow. simulation for the 19761980 period. 
Good field values for dispersion would have been helpful but it is unlikely that the relative impact of the Cold Creak Irrigation described herein would be substantially altered by improved dispersion data. The results of the HPCP model confirm the fact that heavy Cold Creek Valley discharge, would have only a minimal impact. upon the waste movement from the high-level waste areas. At present the HPCP model uses surfaces produced by the VTT flow model but does not incorporate the boundary calculational types of the VTT model as shown in Figure 5.. Thus in the present pathline formulation a pathline/streamiline can terminate at an internal boundary (see streamline 12, Figure 10). Incorporation of calculational types into the HPCP model would greatly reduce this problem.

Some uncertainty exists as to the impact of withdrawing the irrigation water from the confined aquifer system beneath the water table aquifer. An analysis of: such impact should be performed prior to heavy water withdrawals from the confined aqquifer system in the cold Creek valley.

\section{HYPOTHETICAL TANK LEAK AND WASTE RECOVERY}

Simulation of the hypothetical tank leak and recovery operation was al so performed with both the VTT and MMT-DPRW models. The HPCP model was used to evaluate the expected ultimate contaminant discharge to the Columbia River: This application was rather involved in that numerous runs were required to obtain the predictions many of which were required to determine the appropriate spatial and time scales. A large region simulation was performed which provided a prediction of the effective aquifer stresses and boundary conditions and a potentiometric surface from which boundaries were interpolated: for the subregional model.." The subregional model was then used to resolve the local detail of tank leak and recovery operations. The position of the subregion is shown on Figure " 4 .

After the initial survey runs were made to determine the time and spatial scaling required, the base set of: runs were made. These 
included simulation of the tank leak and the 30 days of spreading before recovery operations began.

\section{ADDITIONAL SIMPLIFICATIONS AND APPROXIMATIONS}

Apart from the basic assumptions given in the problem statement or in published reports, the following Model. simplifications were used in preparing the simulations:

1. the waste was presumed to have the physical and chemical properties of ambient water,

2. the ${ }^{106} \mathrm{Ru}$ reaching the ground water did not interact with the sediment,

3. the waste was assumed mixed over a total depth of 10 feet ( 3 meters) at all times,

4. the longitudinal and lateral dispersivities used were 10 feet ( 3 meters) and 6 feet ( 1.8 meters) respectively,

5. a total of 9600 parcels were used to model movement of the 47,310 curies of ${ }^{106}$ Ru so that each parcel represented about 5. curies of ${ }^{106} \mathrm{Ru}$,

6. the 250,000 gallons $(950,000$ liters $)$ of waste entered the ground water over a period of one day, and

7. injection fluid was assumed to be ambient water since two-phase modeling capability is not currently available.

The high-level radioactive wastes stored at Hanford are often a highly viscous, caustic, and thermally hot liquid with a mass density higher than ambient water. An important factor to consider, however, is the apparent dilution of the waste by the time recovery operations are initiatẹd.

In this study, the contaminated liquid has been diluted from 250,000 gallons $\left(9.5 \times 10^{5} 1\right.$ iters $)$ to about $7,200,000$ gallons $\left(2.7 \times 10^{7}\right.$ liters) so that the volume has increased by a factor of 29. A dilution of this magnitude would cause the waste to rapidiy assume the characteristics 
of ambient ground water. Nevertheless a precise prediction of the chemical and physical characteristics of the system during the initial movement of the waste in the groundwater flow system would likely require a complete analysis of both the waste and the porous medium and a thorough knowledge of the reactions (including the kinetics) involved: The actual movement of the waste immediately after introduction into the ground water and prior to significant dilution may deviate from the predicted waste movement presented herein (in which the waste is assumed to have the properties of ambient ground water) in several qualitative ways:

1. The elevated waste temperature would tend to cause the waste to remain near the water table.

2. High viscosity would reduce the spreading and mixing of the waste with the ground water.

3. The causticity may alter the physical characteristics of the sediment and therefore cause limited changes in the local flow system.

4. The high density of the waste would tend to cause greater vertical penetration into the aquifer.

Quantitative analysis of each of these characteristics and a determination of the net effect is beyond the scope of this study.

\section{RESULTS}

Subsequent to the initial survey areas to determirie time and spatial scaling, the models were used to simulate the 30 day period between entry of the waste into the ground water and initiation of recovery operations. The subregion potential contours immediately prior to entry of the waste into the ground water are shown in figure 13. Figure 14 shows the subregion potential contours immediately following the waste entry into the ground water. 


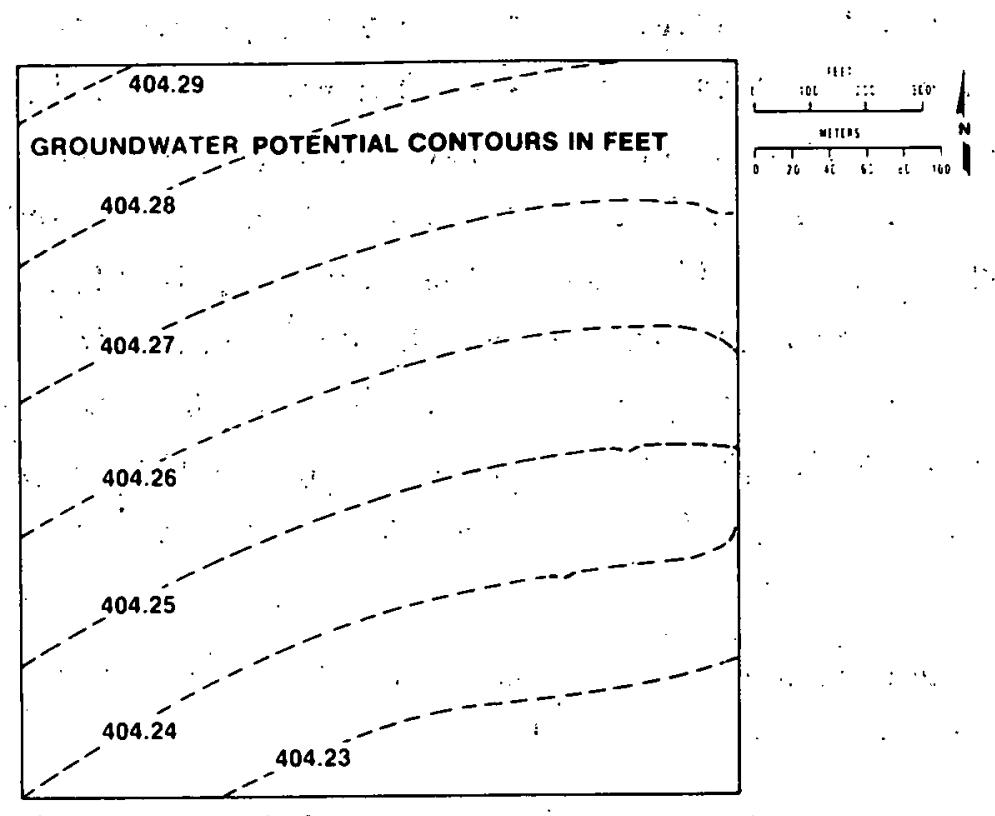

FIGURE 13

PREDICTED SUBREGION POTENTIAL CONTOURS PRIOR TO ENTRY OF HYPOTHETICAL TANK LEAK WASTE INTO GROUND WATER

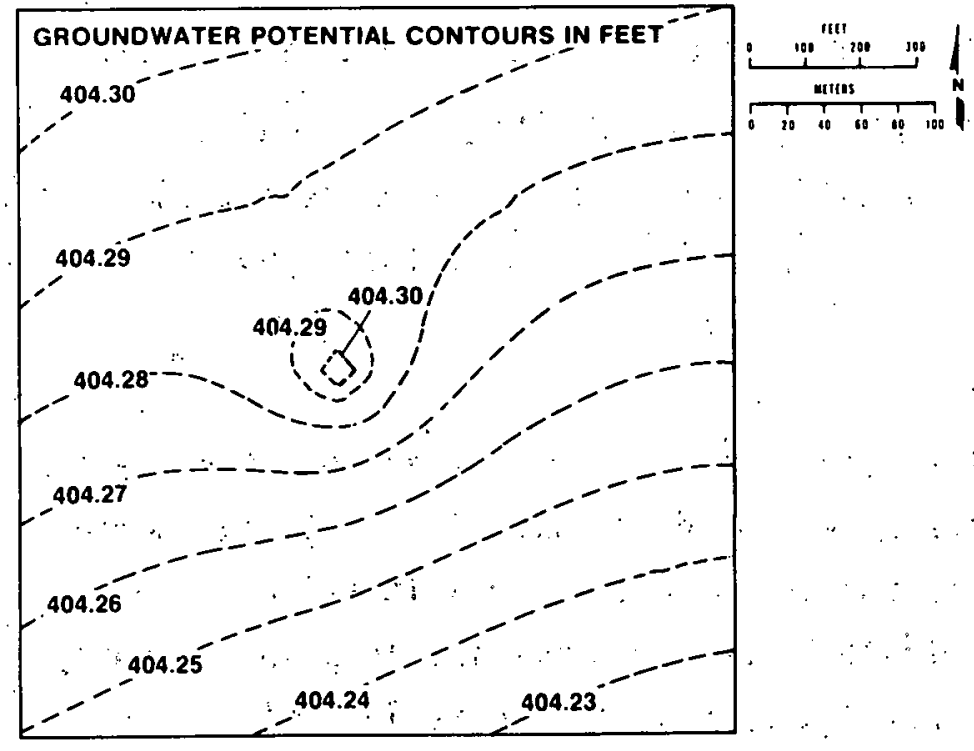


Because of the relatively high transmissivities in the 200 East Area and the relatively small injection. rate $174 \mathrm{gpm} \cdot(660 \mathrm{lpm})$ required to release 250,000 gallons $(950,000$ liters) of waste in cne day, a very small potential mound of less than 0.03 feet above ambient was predicted. During the 30-day period between waste entry and the beginning of recovery operations (Figure 15) the "mound" has almost completely dissipated and the corresponding concentration plume has spread only about 350 feet (107 meters) in diameter (Figure 16).

Various recovery operations were simulated to determine the best strategy. These included single recovery wells at various positions and rates, single recovery wells with multiple injection wells to retard the spreading and movement of the contaminant plume and multiple recovery wells. Single recovery wells were not as effective in recovering the waste as multiple wells pumping the same total amount. Injection wells also appeared to be of little to no value in this situation because only smal. local gradients were present. . The effective configuration consisted of three wells approximately 30-35 feet $(9-11 \mathrm{~m})$ apart in a triangular pattern with the well (A) at the top of the triangle at the tank leak site and the two other wells ( $B$ and $C$ ) positioned down gradient of the first well. The groundwater potentials and waste concentration contours after 60 days of recovery pumping at $50 \mathrm{gpm}(190 \mathrm{lpm})$ for each of the three wells are shown in Figures 17 and 18 respectively. At this point the groundwater potential contours had reached a steady condition. The ruthenium-106 concentration contours after 90 and 240 days of recovery pumping at the same, rate are shown in Figures 19 and 20 .respectively.

In order to demonstrate the effect of pumping rate on the recovery operation, the pumping rate for Well. A was increased to $125 \mathrm{gpm}$ and that for Wells $B$ and $C$ were increased to $100 \mathrm{gpm}$. Again, the potential field had reached steady state after 60 days of recovery pumping at the new total rate of $325 \mathrm{gpm}$ (Figure 21). The ruthenium-106 concentrations within the groundwater system are shown in Figures 22 and 23 after 60 and 135 days of recovery pumping respectively. 


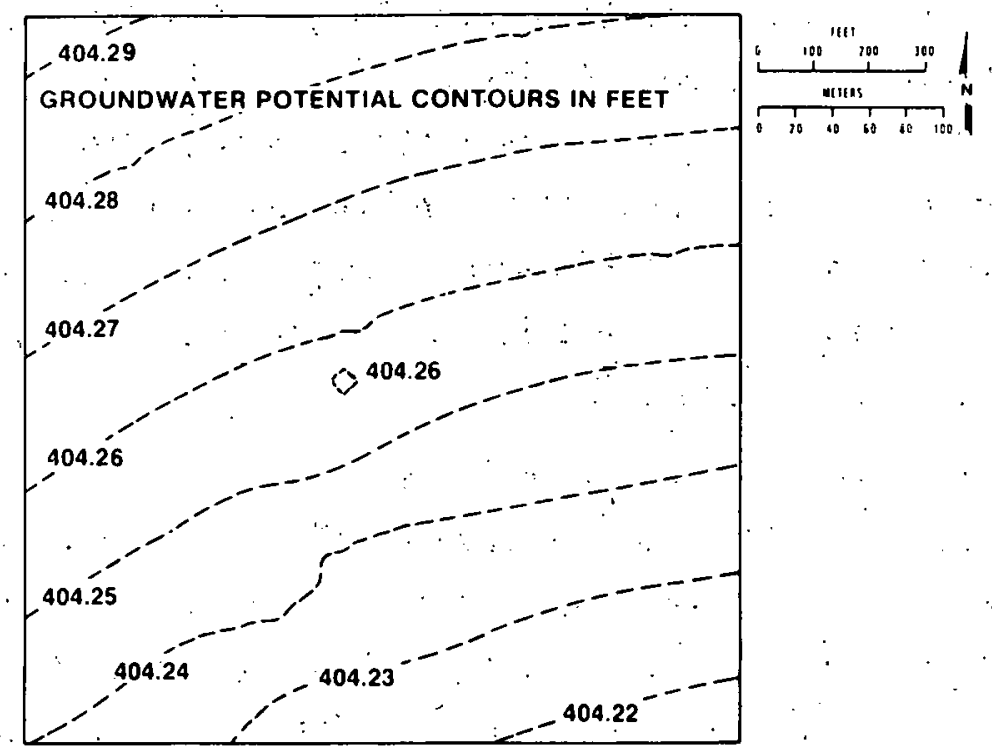

FIGURE 15

PREDICTED SUBREGION POTENTIAL CONTOURS 31 DAYS AFTER WASTE ENTRY INTO GROUND WATER AND IMMEDIATELY PRIOR TO RECOVERY OPERATIONS






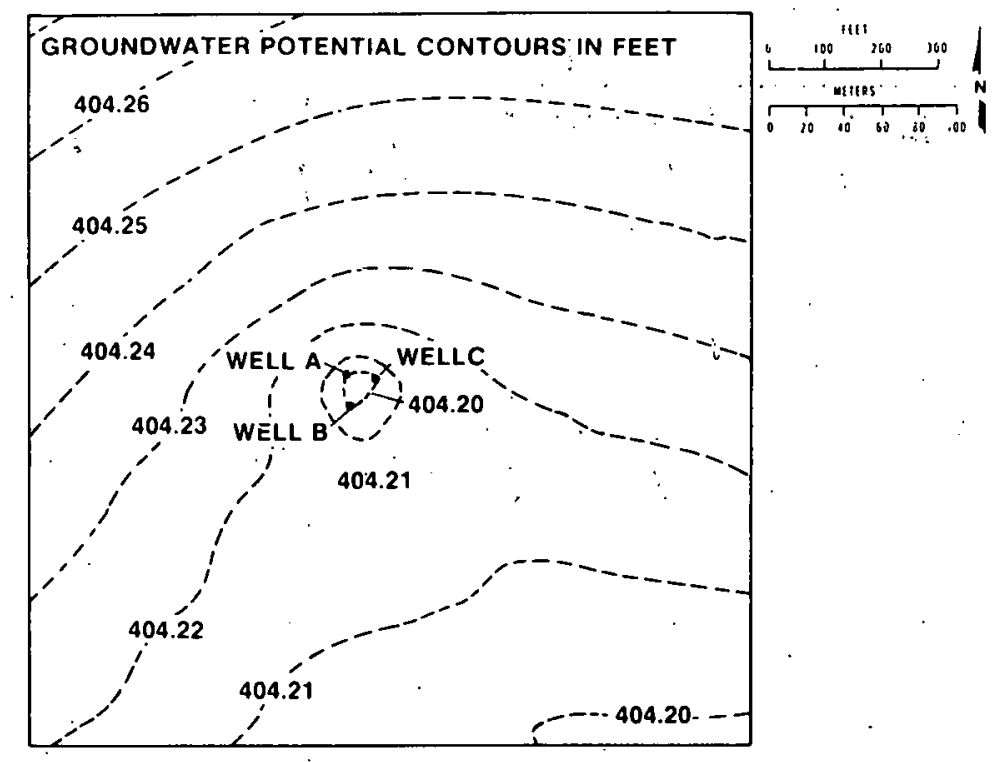

FIGURE 17

PREDICTED SUBREGION POTENTIIAL CONTOURS AFTER 60 DAYS OF RECOVERY PUMPIING AT 150 GPM (50 GPM FOR EACH OF 3 WELLS)

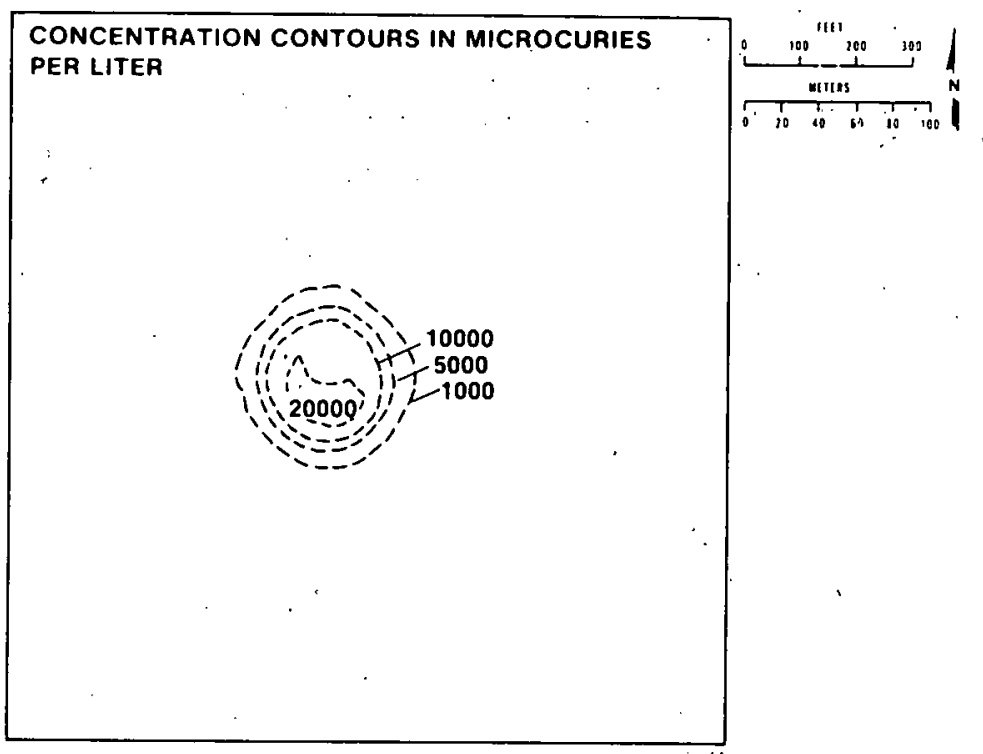

FIGURE 18

RUTHENIUM-106 CONCENTRATION CONTOURS AFTER 60 DAYS OF RECOVERY PUMPING AT 150. GPM (50 GPM FOR EACH: OF. 3 WELLS) 


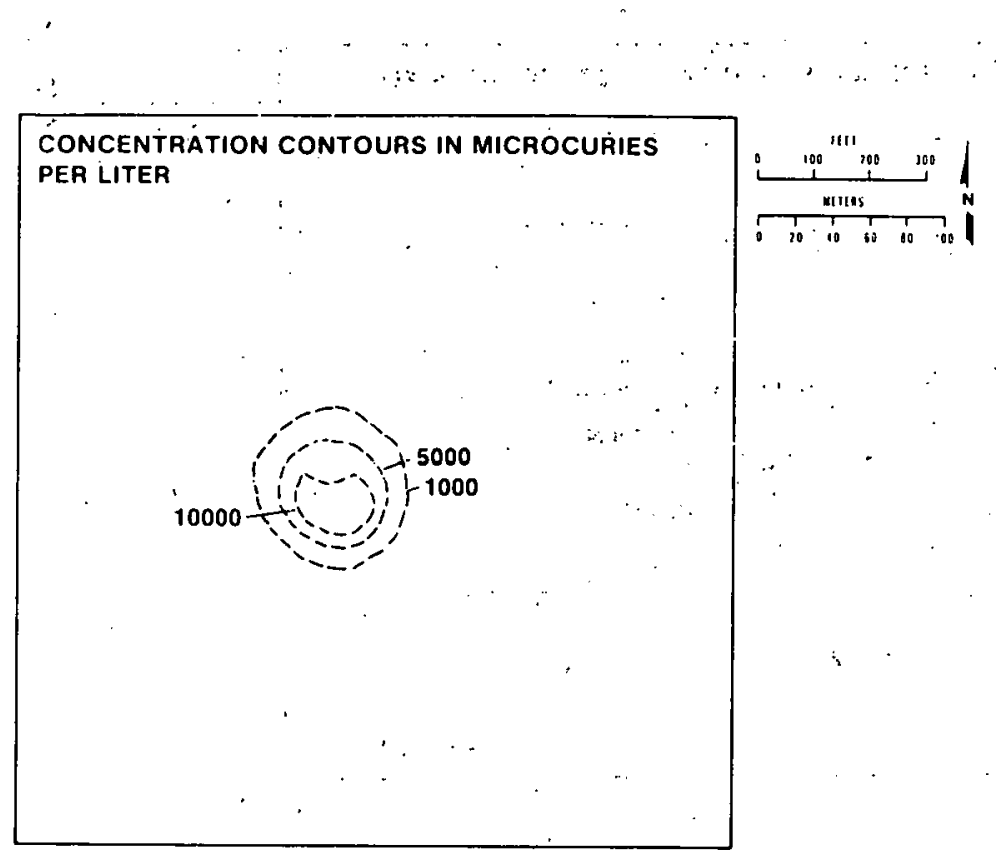

FIGÜRE 19:

\section{RUTHENIUM-106. CONCENTRATION CONTOURS AFTER 90 DAYS \\ OF RECOVERY PUMPING AT $150 \mathrm{GPM}$ \\ (50 GPM EACH FOR 3 WELLS)}

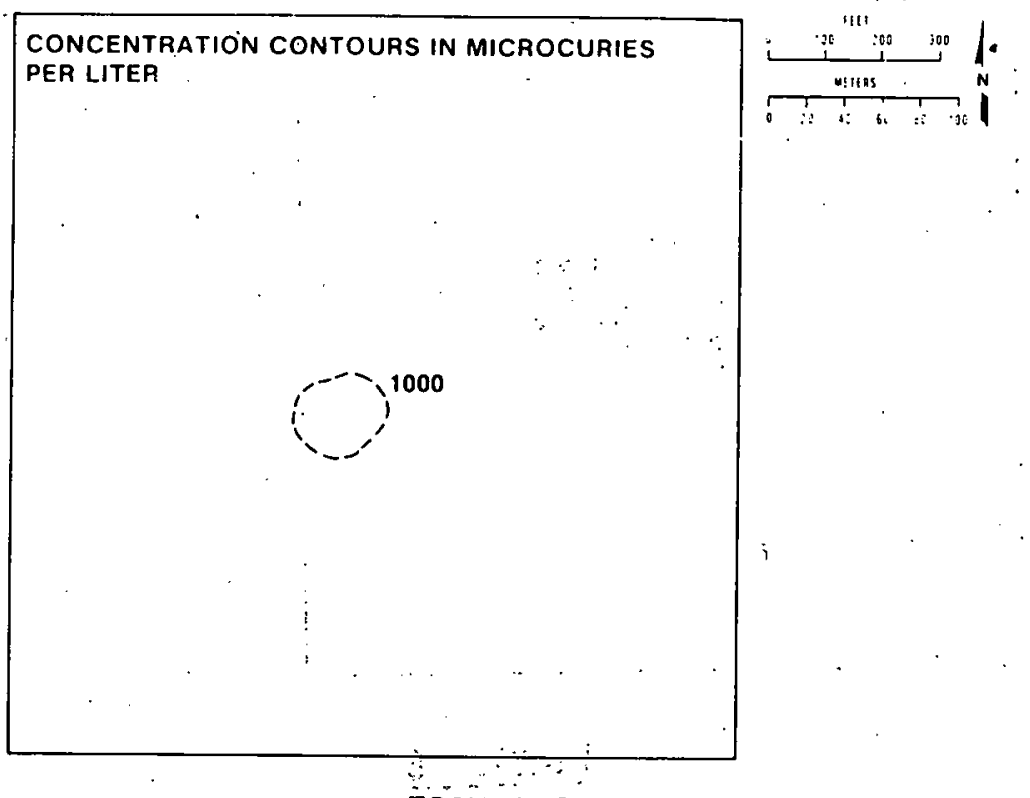

FIGURE, 20

RUTHENIUM-106 CONCENTRATION CONTOURS AFTER 240 DAYS

OF RECOVERY PUMPING AT $150 \mathrm{GPM}$

(50 GPM EACH FOR 3 WELLS) 


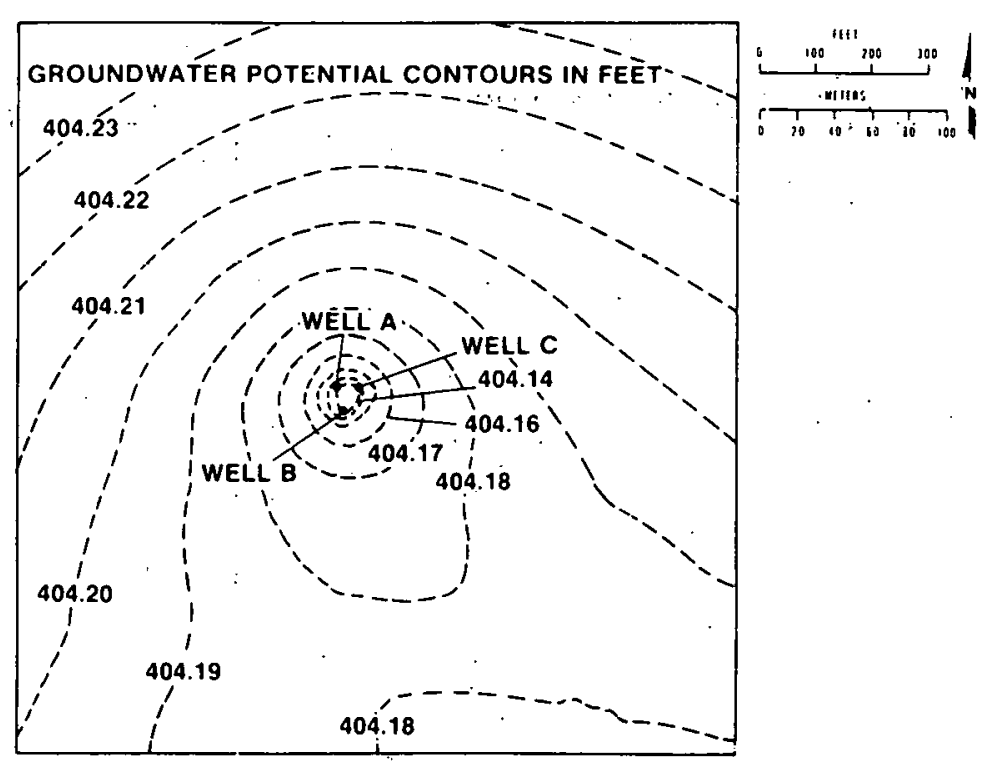

FIGURE 21

SUBREGION POTENTIAL CONTOURS AFTER 60 DAYS OF. RECOVERY PUMPING AT: 325 GPM ( 125 GPM AT WELL A, AND 100 GPM EACH AT WELLS B AND C)

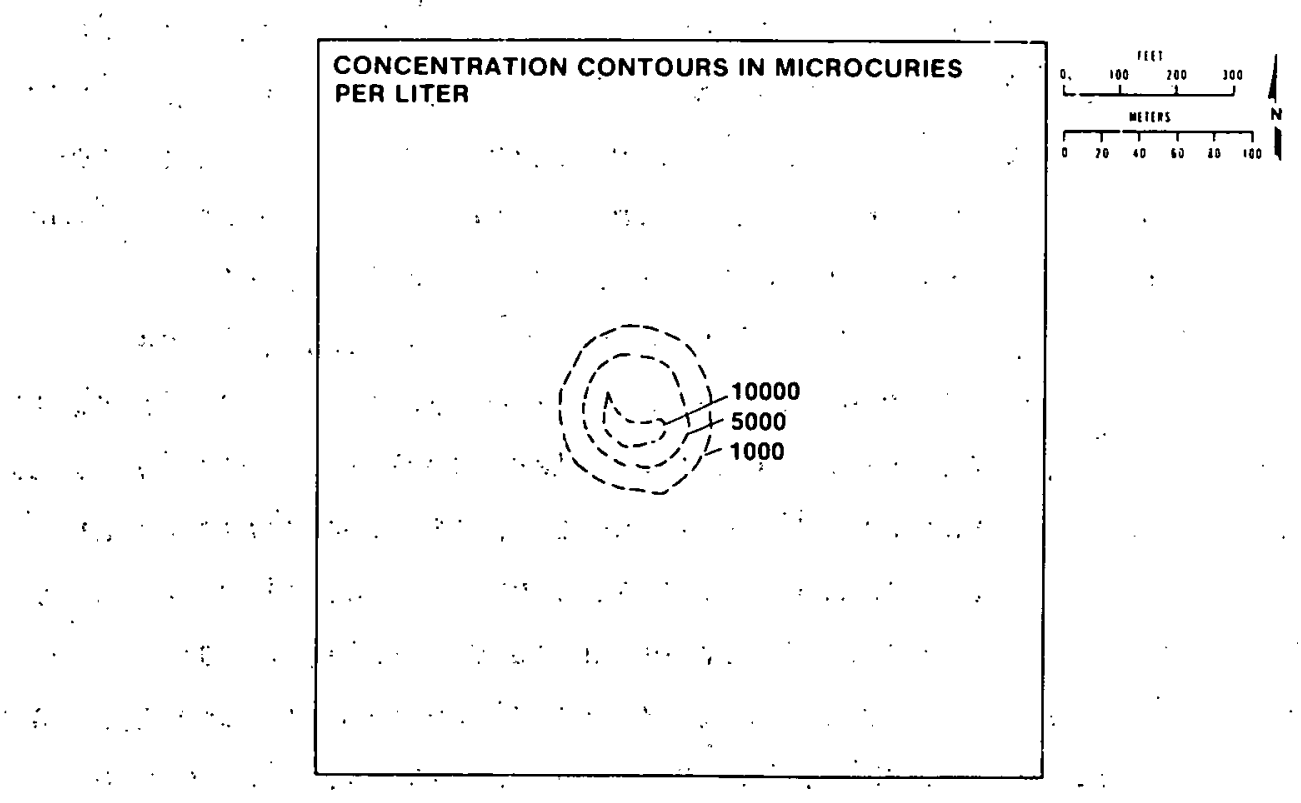

FIGURE 22

RUTHENIUM- 106 CONCENTRATION CONTOURS AFTER 60 DAYS OF RECOVERY PUMPING AT.325 GPM (125 GPM AT WELL A AND $100 \mathrm{GPM}$ EACH AT WELLS B AND C) 


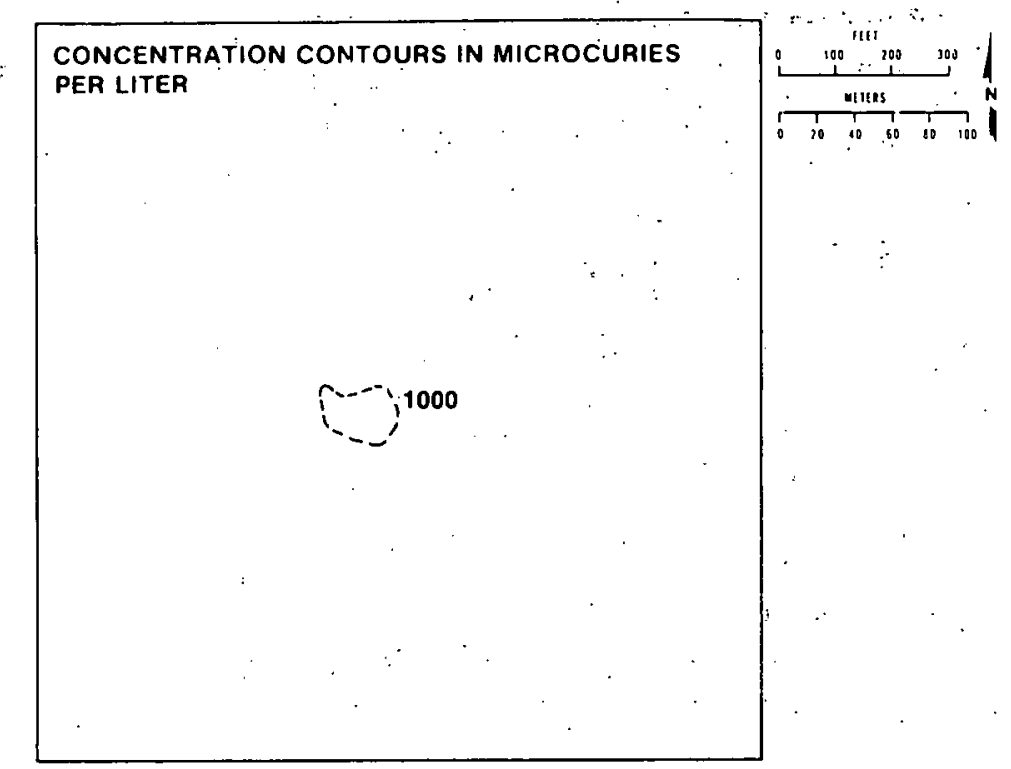

FIGURE: 23

RUTHENIUM-106 CONCENTRATION CONTOURS AFTER 1:35 DAYS OF RECOVERY PUMPING AT 325 GPM (125 GPM. AT WELL A AND 100 GPM E.ACH AT WELLS B AND C)

The calculated waste concentration over the pumping period has been reduced by dilution and withdrawal from 50,000 microcuries/1iter to 1,000 microcuries per liter. This represents a concentration reduction factor of 50. The total volume of ground water with a contaminant concentration of 1,000 microcuries/liter was calculated by estimating the contaminant volume in Figure 20 ( $150 \mathrm{gpm}$ withdrawal pumping rate 240 days) to be $1.5 \times 10^{6}$ gallons. From this volume, the total radioactivity remaining in the ground water arising from the hypothetical tank leak was calculated to be 5,700 curies. The original 250,000 gallons of waste contained about 47,000 curies so that a total contaminant mass (curie) reduction factor of approximately 8 has been achieved. In order to conveniently predict the groundwater contamirztion with concentration reduction factors greater than 50, minor modifications in the MMT-DPRW code are necessary. Because of the localized nature of the hypothetical tank leak, a single streamline was drawn from the tank leak location to the Columbia River (Figure 24). 


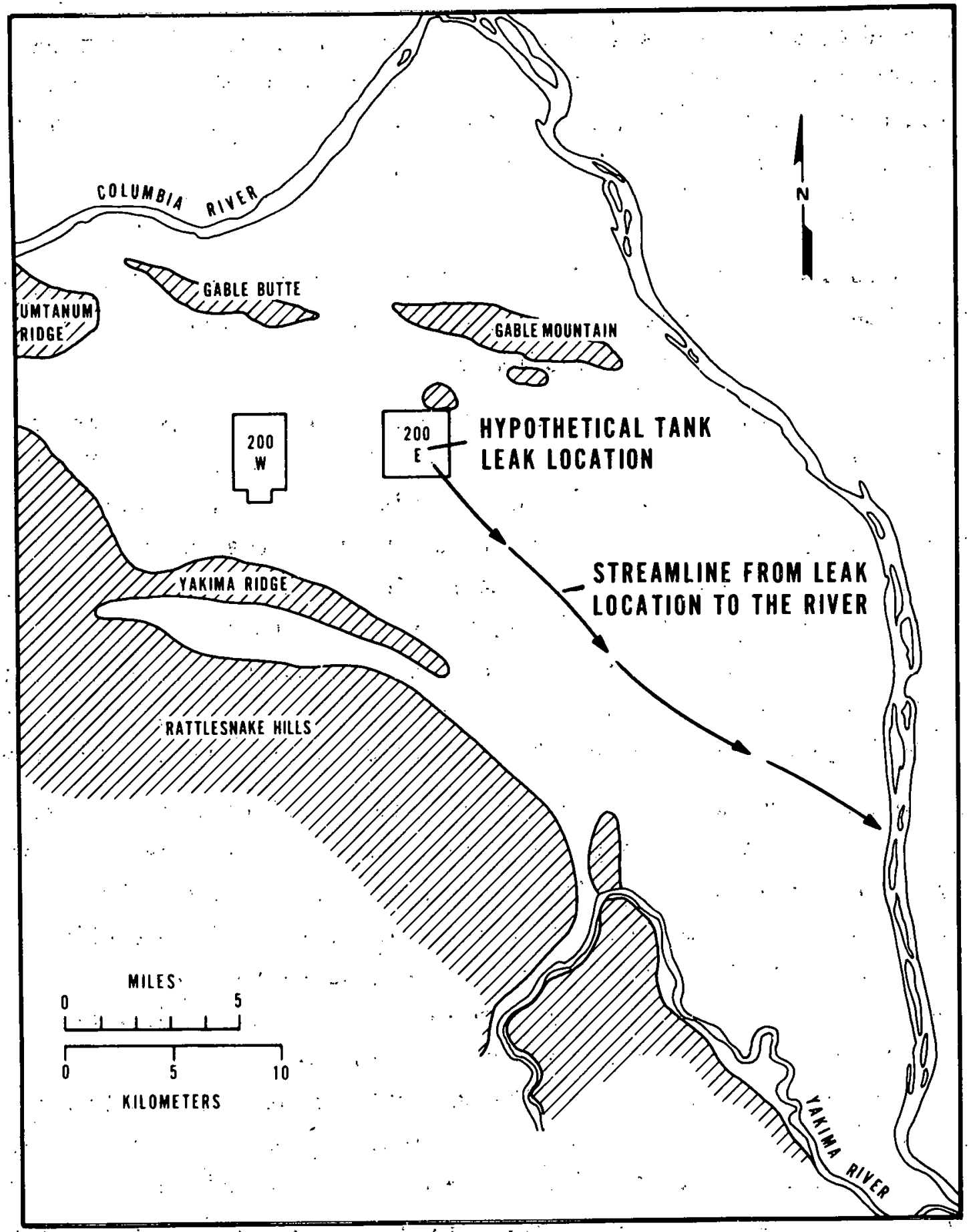

\section{FIGURE 24}

STREAML INE FROM THE HYPOTHETICAL TANK LEAK LOCATION

TO THE COLUMBIA'RIVER (TRAVEL DISTANCE $=17.5$ MILES, TRAVEL TIME $=.125$ YEARS) 
The predicted travel distance was 17.5 miles and the predicted travel time was 125 years. A 125 year delay before discharge to the Columbia River would cause the concentration of ${ }^{106} \mathrm{Ru}$ to drop below detectible limits even if no further dilution were to occur.

EVALUATION

A comparison of Figure 20 with Figure 23 demonstrates that the cleanup operation was accelerated in time with the higher pumping rate; however a higher volume of recovered solution was produced.

It should be noted that the wastewater created by these pumping schemes occupies a very 1 arge volume $\left(7 \times 10^{7}\right.$ gallons $\left(2.4 \times 10^{8}\right.$ liters $)$ after 135 days for the $325 \mathrm{gpm}$ case). This scenario was chosen to illustrate a worst case type of example. The recovery wells were assumed to be withdrawing over the entire depth of the aquifer because of the vertically averaged restriction of the models, the effective porosity was set at $0: 25$, and the transmissivities in the study region were among the largest in the Hanford matrix. All of these factors contributed toward the predicted large volume of water withdrawal necessary to remove the contaminant.

Beçause the waste would not be expected to be immediately mixed. throughout the entire aquifer depth an actual recovery operation of this type would likely use partially penetrating recovery wells. Such wells would withdraw from the upper (contaminated) portion of the aquifer and therefore result in a much smaller volume of wastewater produced for the same quantity of waste recovered. Analysis of this more realistic condition would require the application of three-dimensional flow and transport model ing capability. The necessity of somewhat arbitrarily selecting a constant mixing depth of 10 feet ( 3 meters) also emphasizes the dimensional limitation of the current models for this type of problem. Three-dimensional flow and transport models are currently being developed by the Atlantic Richfield Hanford Company.

It should be noted that the contents of an actual liquid high-level radioactive waste tank at Hanford include a variety of radionuclides several of which are highly sorbed onto the Hanford sediment. [12] Introduction of such a solution. into the saturated groundwater zone would result in those nuclides becoming rapidly immobilized. Such a condition is desirable 
in preventing the movement of the waste to the biosphere but also limits the recovery of such radionuclides by the pumping technique herein described unless some means of desorption is provided.

In spite of the limitations, this study indicates that positive corrective action can be considered for control management in the unlikely event that substantial amounts of high-level waste are introduced into the Hanford saturated groundwater zone.

\section{CONCLUSIONS}

The results of the Cold Creek Valley Irrigation Study indicate that heavy agricultural irrigation in the valley is unlikely to cause significant changes in the water table underlying the high-level waste areas nor in the movement of radionuclides already in the ground water. Although some limitations of the present Hanford groundwater modeling capability were identified for this type of comparison, such limitations are of secondary importance and are unlikely to affect the overall conclusion.

The hypothetical tank leak and recovery study showed that onsite computer technology can be used to model waste recovery operations over 'small areas. However, the usefulness of the existing modeling capability for such simulations is limited. Research is now underway to correct these weakness. The tank leak study did confirm that waste management control does provide a possible active (waste recovery) alternative in contrast to passive monitoring of a contaminant incident. 


\section{REFERENCES}

1. R. A. Deju, R. E. Gephart, "Hydrologic Management at the Hanford Nuclear Waste Facility," ARH-SA-235, Atlantic Richfield Hanford Company, Richland, Washington, 993521975.

2. D. A. Myers, et. al., "Environmental Monitoring Report on the Status of Ground Water Beneath the Hanford Site, January-December 1975," BNWL-2034, Battelle, Pacific Northwest Laboratories, Richland, Washington, 1976.

3. R. C. Arnett, et. al., "Conceptual and Mathematical Modeling of the Hanford Groundwater Flow Regime," ARH-ST-140, Atlantic Richfield Hanford Company, October, 1976.

4. "Irrigation Water Requirements, Estimates For Washington" Washington State Agricultural Experiment Station Circular 512; November 1969.

5. "Water Table Measurement Data Maps - December 1976," H-2-38396, Rev. I, Staff, Research Department, Atlantic Richfield Hanford Company, January 1976.

6. "Preliminary Feasibility Study on Storage of Radioactive Wastes in Columbia River Basalts," ARH-ST-137, Staff, Research and Engineering Division, Atlantic Richfield Hanford Co., November 1976.

7. R. A. Deju and W. K. Summers, "Transmissivity and Hydraulic Conductivity of Saturated Sedimentary Rocks in the Hanford Reservation, "CA-168-RAD-5, R. A. Deju and Associates Report to Atlantic Richfield Hanford Company under ERDA Contract AT(45-1)-2120, 1975.

8. D. J. Brown, "Subsurface Geology of the Hanford Separation Areas," HW-61780, General Electric Company, Richland, Washington, October 1959.

9. K. L. Kipp, A. E. Reisenauer, C. R. Cole, and C. A. Bryan, "Variable Thickness Transient Groundwater Flow Model Theory and Numerical Implementation," BNWL-1703, Battelle Pacific Northwest Laboratories, 1972 (Updated 1976).

10. D. B. Cearlock, K. L. Kipp, and D. R. Friedrichs, "The Transmissivity Iterative Calculation Routine - Theory and . Numerical Implementation," BNWL-1706, Battelle Pacific Northwest Laboratories, 1972, (revised 1976).

11. S. W. Ahistrom, et. al., "Multicomponent Mass Transport-Discrete Parcel Random Walk Model Theory and Numerical Implementation," BNWL-2127, Battelle Pacific Northwest Laboratories, May 1977. 
12. "Final Environmental Statement;" Waste Management Operations, Hanford Reservation, Richland, Washington," ERDA-1538, United States Energy Research and Development Administration, December 1975. 
No: of

Copies

Atlantic Richfield Hanford Company

R. C. Arnett (30)

H. Babad

R. G. Baca

G. S. Barney

D. J. Brown

R. A. Deju

P. A. Eddy

P. G. Easley

R. D. Fox

R. E. Gephart

M. Grutzeck

R. E. Isaacson

R. K. Ledgerwood

M. W. Legatski

J. V. Panesko

W. H. Riggsbee

H. P. Shaw

D. D. Woodrich

ARHCO Document Control (28).

ERDA Richland Operations office

0. J. Elgert

J. L. Rhoades

P. G. Rhoades

J.A. Fernandez

Rockwell Internationa 1

D. J. Cockeram

W. F. Heine

R. J. Gimera

\section{Battelle-Northwest}

S. W. Ahlstrom

H. C. Burkholder

D. B. Cearlock

C. R. Cole

J. R. Eliason

D. R. Friedrichs

K. M. Harmon

B. W. Mercer

D. A. Myers

J. R. Raymond
No. of

Copies

Battelle-Northwest (cont.)

A. E. Reisenauer

A. K. Tyagi

J. F. Washburn

United Nuclear Inc.

A. L. Cucchiara

Westinghouse Hanford Company

R. B. Hall

Boeing Computer Services, Richland

R. W. Helson 